\title{
Microtopography Controls of Carbon and Related Elements Distribution in the West Siberian Frozen Bogs
}

\author{
Sergey Loiko ${ }^{1, *(\mathbb{C})}$, Tatiana Raudina ${ }^{1}$, Artem $\operatorname{Lim}^{1}{ }^{1}$, Daria Kuzmina ${ }^{1}$, Sergey Kulizhskiy ${ }^{1}(\mathbb{C}$ \\ and Oleg Pokrovsky ${ }^{1,2}$ (D) \\ 1 BIO-GEO-CLIM Laboratory, National Research Tomsk State University, Lenina St. 36, 634050 Tomsk, Russia \\ 2 Geoscience and Environment Toulouse, UMR 5563 CNRS, University of Toulouse, 14 Ave Edouard Belin \\ 31400 Toulouse, France \\ * Correspondence: s.loyko@yandex.ru
}

Received: 31 May 2019; Accepted: 28 June 2019; Published: 30 June 2019

check for updates

\begin{abstract}
The West Siberian Plain stands out among other boreal plains by phenomenal bogging, which has both global and regional significance. The polygonal bogs, frozen raised-mound bogs, and ombrotrophic ridge-hollow raised bogs are the most extensive bog types in the study area. These bogs commonly show highly diverse surface patterns consisting of mounds, polygons, ridges, hollows, and fens that correspond to the microtopes. Here we investigated how the microtopographic features of the landscape affect the thermal and hydrologic conditions of the soil as well as the nutrient availability and consequently, the dynamics of carbon and related elements. The effect of the surface heterogeneity on the temperature regimes and depths of permafrost is most significant. All of these factors together are reflected, through the feedback system, by a number of hydrochemical parameters of bog waters, such as dissolved organic and inorganic carbon (DOC, DIC), specific conductivity (Cond), $\mathrm{SO}_{4}{ }^{2-}, \mathrm{Cl}^{-}, \mathrm{P}, \mathrm{Sr}, \mathrm{Al}, \mathrm{Ti}, \mathrm{Cu}, \mathrm{V}, \mathrm{B}, \mathrm{Cs}, \mathrm{Cd}, \mathrm{Rb}, \mathrm{As}, \mathrm{U}$, and rare earth elements (REEs). Among the studied parameters, $\mathrm{DOC}, \mathrm{SO}_{4}{ }^{2-}, \mathrm{Al}, \mathrm{V}$, and $\mathrm{Mn}$ differ most significantly between the convex and concave microforms. The DOC content in bog water is significantly affected by the water residence time, which is significantly longer in soils of mound/polygons than fens. Plants biomass is higher on the mounds which also have some effect that, due to leaching, should lead to more carbon entering into the water of the mounds. It is also shown that atmospheric-dust particles have a noticeable effect on the hydrochemical parameters of bog waters, especially on mounds. The ongoing climate warming will lead to an increase in the fens area and to a decrease in the content of DOC and many elements in bog waters.
\end{abstract}

Keywords: frozen bogs; ombrotrophic ridge-hollow raised bogs; surface bog patterning; bog water; Histosols; Western Siberia Lowland (WSL)

\section{Introduction}

The West Siberian Plain stands out among other boreal plains due to its phenomenal bogging, which has both global and regional significance as a result of its strong influence on hydrochemical parameters of rivers [1-6]. Identified in Western Siberia study patterns of wetlands functioning can be extended to other less waterlogged areas of the boreal and subarctic zones. The bogs have even greater influence on the elemental composition of dissolved and colloidal fractions of lakes which are located within the bog massifs [7]. Bogs significantly affect biological productivity in the Kara Sea by influencing the delivery of chemical elements from land [8,9]. Moreover, via thermal insulation and water retention properties, they contribute to the penetration of permafrost far to the south, up to the latitude of the southern taiga [10]. 
The wetlands of Western Siberia not only affect all components of landscapes, but also themselves depend on changes in external factors, and especially climate. Under climate warming, frozen bogs will experience the most dramatic changes compared to others. These changes are associated both with the restructuring of bog landscapes and the thawing of frozen peat and its involvement in biogeochemical cycles. The continued warming and humidification of the climate in the north of Western Siberia is an established fact [11,12], although it proceeds at a variable speed [13]. In this regard, questions about the prediction of changes in the environment-forming role of wetlands at the regional and global levels as well as about the features of the interaction of wetlands and adjacent geosystems in new climatic realities are becoming more relevant. Thus, it is predicted that an increased thickness of the active layer (seasonally thawed layer) of bogs within the permafrost zone will enhance the export of dissolved organic carbon (DOC) from peat soils to aquatic systems [14,15]. Together with DOC, the fluxes of elements associated with organic matter will also change. Therefore, much attention is paid to the wetland systems area within the permafrost zone [16-18].

If we rescale up the consideration of wetlands from the regional to the local level, then significant spatial heterogeneity will be detected. This is expressed by the different structures of peat deposit, the temperature conditions, the peat accumulation rates, and the elemental composition of peat deposits. Two main land cover types provide this micro-heterogeneity: Peat plateaus (mounds or polygons) and depressions (hollows, fens). This microtopography strongly affects the thermal and hydrologic conditions of the soil, nutrient availability, plant species distribution, and consequently, the carbon and related elements dynamics of these Arctic regions [19-22]. It is obvious that the responses of different land cover types to climate change will not be the same, since the indicated forms are contrasted by morphological, phytocenotic, and functional characteristics. The contributions of mounds and fens to the formation of hydrochemical runoff from bogs and flows of greenhouse gas are unequal [23-26]. Thus, peat plateaus are hydrologically important to basin drainage, as they generate a large amount of runoff for stream flow [27]. Several studies have shown that the spatial and temporal variation in the patterns are large, even over the scale of meters [20,23]. It is necessary to characterize the ecosystem functioning in the different microtopographic features in order to simulate the future state of bogs and their external relations with other geosystems and to understand and predict the impact of climate change. There is still not enough information about the degree of contrast in the conditions emerging in these land cover types, the history of their development, and the possibility of mutual transition. This, in turn, makes it difficult to predict the state of wetlands in new climatic realities. Therefore, the present study is aimed at filling this knowledge gap and provides new scientific understanding of the contrasting hydrochemical parameters of bog waters in the soil of mounds and hollows of the West Siberian frozen bogs.

\section{Materials and Methods}

The study area was located in the northern part of the West Siberian Lowland (WSL) within three major boreal biomes (taiga, forest-tundra, and tundra). The territory investigated in this work included sporadic, discontinuous, and continuous permafrost zones (Figure 1). The area is representative of the WSL with flat, low-lying interfluvial areas, well-developed river and stream networks, numerous lakes, and it exhibits a high degree of paludification. The region is within the watershed of the Ob, Nadym, Pur, and Taz rivers which drain Pleistocene sands and clays and are covered by a 1 to $5 \mathrm{~m}$ peat layer. The climate is humid semi-continental with an average annual temperature fluctuating from $-2.8^{\circ} \mathrm{C}$ in the south (Surgut region) to $-9.1{ }^{\circ} \mathrm{C}$ in the north (Tazovsky region). The annual precipitation ranges from $600 \mathrm{~mm}$ in the south to $360 \mathrm{~mm}$ in the north [28].

Along the latitudinal transect, we selected five sampling sites whose physico-geographical characteristics are given in Table 1. The southernmost key site (KS), Kogalym or Kog $\left(62,25^{\circ} \mathrm{N}\right.$, $74,19^{\circ} \mathrm{E}$ ), was located in the northern part the ombrotrophic ridge-hollow bogs distribution (northern taiga). Three sampling sites were located on the frozen bogs (palsa) of the northern taiga (KS: Khanymey or Kha, $63,78^{\circ} \mathrm{N}, 75,61^{\circ} \mathrm{E}$ ), the forest-tundra (KS: Pangody or Pan, $65,87^{\circ} \mathrm{N}, 74,96^{\circ} \mathrm{E}$ and Urengoy or 
Ure, $66.09^{\circ} \mathrm{N}, 78.72^{\circ} \mathrm{E}$ ). The northernmost $\mathrm{KS}$ was located on frozen polygonal bogs in the southern tundra. (KS: Tazovsky or Taz, $67,37^{\circ} \mathrm{N}, 78,68^{\circ} \mathrm{E}$ ).

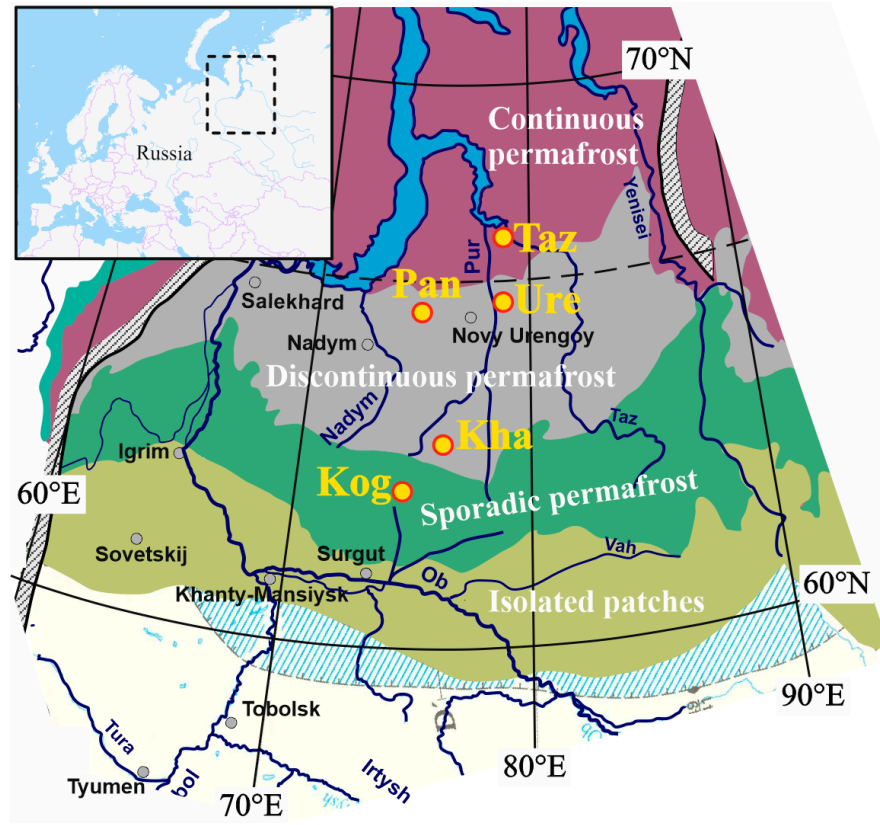

Figure 1. Map of the study site with permafrost boundaries [29], http://portal.inter-map.com, NSIDC, with five main test sites: Taz-Tazovsky; Ure-Urengoy; Pan-Pangody; Kha-Khanymey; and Kog-Kogalym.

The polygonal bogs, palsa (frozen raised-mound bog), and ombrotrophic ridge-hollow raised bogs are the most extensive mire types of the study area. These bogs commonly show highly diverse patterns consisting of mounds (hummocks), polygons, ridges, hollows, and fens that correspond to the microtopes [30-33] (Figure 2). In our study, the mounds, polygons, and ridges were considered to occupy the eluvial landscape position and develop with a typically lower hydraulic conductivity. They have flat to convex transverse profiles. The hollows correspond to transient positions and the fens are located at the accumulative positions. They have a large catchment area, develop on wetter sites, have a concave form, and differ in the degree of flow and closure. The ridge in the ridge-hollow complex, the mound in the mound-hollow complex, and the polygon in the polygonal complex are considered autonomous primary geochemical l6gtandscapes. The hollow in the ridge-hollow complex and the fen are geochemically subordinate landscapes. The arrangement and combination of these microtopes and microforms create a variety of mire types or mire units (mesotope level) [30-33]. On mounds and polygons, the upper $50 \mathrm{~cm}$ of peat deposits consist mainly of residues of dwarf shrubs, hypnum mosses, grasses, lichens, sphagnum mosses (Sphagnum fuscum, S. majus) and, less commonly, wood. In the fens or hollows, the upper $50 \mathrm{~cm}$ of peat deposits consist mainly of sphagnum mosses, cotton grass, sedges, and less commonly, grasses. Deeper than $50 \mathrm{~cm}$ in the fens, peat usually lies, which is similar in composition to peat of the mounds. On average, the decomposition degree of the upper part of the peat deposit on the mounds is 1.6 times higher than in the fens. To the south, the share of sphagnum mosses, wood residues and lichens in the peat botanical composition of the mounds increases. 
Table 1. Physico-geographical, permafrost, and ecosystem parameters of five key sites.

\begin{tabular}{|c|c|c|c|c|c|c|c|c|c|c|}
\hline Key Site & Latitude ${ }^{\circ} \mathbf{N}$ & $\begin{array}{c}\text { Mineral } \\
\text { substrate }\end{array}$ & $\begin{array}{l}\text { Micro- } \\
\text { topes }\end{array}$ & $\begin{array}{c}\text { Peat } \\
\text { Thickness, } \\
\text { m }\end{array}$ & $\begin{array}{l}\text { ALT, } \\
\text { cm }\end{array}$ & $\begin{array}{c}\text { Peat } \\
\text { Accumu- } \\
\text { lation rate }\end{array}$ & $\begin{array}{l}\text { Biomass, } \\
\mathrm{g} / \mathrm{m}^{2}\end{array}$ & $\begin{array}{l}\text { Mortmass, } \\
\mathrm{g} / \mathrm{m}^{2}\end{array}$ & Vegetation Types and Dominant Plant Species & Soil (WRB, 2014) \\
\hline \multirow[t]{2}{*}{ Taz } & \multirow[t]{2}{*}{67.4} & \multirow[t]{2}{*}{$\begin{array}{l}\text { Clay loam } \\
\text { and loam }\end{array}$} & polygons & $2.0-4.0$ & 41 & 0.02 & - & - & $\begin{array}{l}\text { Dwarf shrub-green mosses-lichen } \\
\text { Betula nana, Ledum palustre, Vaccinium vitisi-idaea, V. } \\
\text { uliginosum, Arctous alpine, Rubus chamaemorus, } \\
\text { Empetrum nigrum, Cladonia stellaris, Alectoria ochroleuca, } \\
\text { Cetraraia nivalis, Sphagnum balticium, } \\
\text { S. fuscum, Drepanocladus ssp., Polytrichum ssp. }\end{array}$ & $\begin{array}{l}\text { Hemic Epicryic Histosols } \\
\text { (Hyperorganic) }\end{array}$ \\
\hline & & & fens & $0.2-1.5$ & 65 & $\begin{array}{c}0.22,0.09 \\
0.21\end{array}$ & - & - & $\begin{array}{l}\text { Sedge-Sphagnum } \\
\text { Carex chordorrhiza, C. rotundata, C. limosa, Eriophorum } \\
\text { polystachyon, Menuyanthes trifoliata, Comarum palustre, } \\
\text { Sphagnum balticum, S. jensenii, S. majus, S. lindbergii }\end{array}$ & $\begin{array}{l}\text { Epifibric Endohemic Cryic } \\
\text { Histosols }\end{array}$ \\
\hline \multirow{2}{*}{ Ur } & \multirow{2}{*}{66.1} & \multirow{2}{*}{$\begin{array}{l}\text { Loam and } \\
\text { silt loam }\end{array}$} & mounds & $2.0-2.5$ & 49 & - & - & - & $\begin{array}{c}\text { Dwarf shrub-green mosses-lichen } \\
\text { Ledum palustre, Vaccinium vitis-idaéa, Rubus chamaemorus, } \\
\text { Empetrum nigrum, Betula nana, Cladonia stellaris, Cl. } \\
\text { rangiferina, Cl. sylvatica, Cetraria cucullata, Shhagnum } \\
\text { balticum, S. fuscum, }\end{array}$ & $\begin{array}{l}\text { Hemic Epicryic Histosols } \\
\text { (Hyperorganic) }\end{array}$ \\
\hline & & & hollows & $0.3-1.2$ & 98 & - & - & - & $\begin{array}{c}\text { Sedge-cotton grass-Sphagnum } \\
\text { Carex rotundata, C. limosa, C, chordorrhiza, Eriophorum } \\
\text { polystachyon, E. russeolum, Scheuchzeria palustris, } \\
\text { Menyanthes trifoliata, Comarum palustre, Sphagnum majus, } \\
\text { S. balticum }\end{array}$ & $\begin{array}{l}\text { Histic Gleysols (Loamic); } \\
\text { Epifibric Histosols }\end{array}$ \\
\hline \multirow[t]{2}{*}{ Pan } & \multirow[t]{2}{*}{65.9} & \multirow[t]{2}{*}{ Loam } & mounds & $0.2-1.4$ & 49 & $0.05,0.11$ & $2200[34]$ & 9000-25000 [34] & $\begin{array}{l}\text { Dwarf shrub-lichens, dwarf shrub-Sphagnum-lichen } \\
\text { Ledum palustre, Betula nana, Andromeda polifolia, Rubus } \\
\text { chamaemorus, Empetrum nigrum, Cladonia stellaris, } \mathrm{Cl} \text {. } \\
\text { rangiferina, Sphagnum fuscum, S. lenense }\end{array}$ & $\begin{array}{l}\text { Hemic Epicryic Histosols; } \\
\text { Histic Cryosols (Loamic) }\end{array}$ \\
\hline & & & fens & $0.3-1.0$ & 82 & $0.23,0.16$ & $750[34]$ & $13000-19000[34]$ & $\begin{array}{c}\text { Sedge-Sphagnum } \\
\text { Carex rotundata, Eriophorum vaginatum, Scheuchzeria } \\
\text { palustris, Sphagnum lindbergii, S. balticum }\end{array}$ & $\begin{array}{l}\text { Epifibric Endocryic Histosols; } \\
\text { Histic Turbic Cryosols (Loamic) }\end{array}$ \\
\hline \multirow{2}{*}{ Kha } & \multirow{2}{*}{63.8} & \multirow{2}{*}{ Sand } & mounds & $0.1-1.4$ & 90 & $0.15,0.28$ & $1200-2400[35]$ & $14000-21000[35]$ & $\begin{array}{l}\text { Dwarf shrub-lichen, dwarf shrub-Sphagnum-lichen } \\
\text { Ledum palustre, Betula nana, Vaccinium vitis-idaea, } \\
\text { Andromeda polifolia, Cladonia stellaris, C. stygia, Rubus } \\
\text { chamaemorus, Shhagnum fuscum, S. capillifolium }\end{array}$ & $\begin{array}{l}\text { Hemic Endocryic Histosols; } \\
\text { Epifibric Endocryic Histosols; } \\
\text { Spodic Histic Turbic Cryosols } \\
\text { (Albic, Arenic) }\end{array}$ \\
\hline & & & fens & $0.4-1.0$ & $>200$ & $0.54,0.96$ & $800[35]$ & $9000-16000[35]$ & $\begin{array}{l}\text { Sedge-Sphagnum, cotton grass-Sphagnum } \\
\text { Eriophorum russeolum, Eriophorum vaginatum, Carex } \\
\text { rotundata, Scheuchzeria palustris, Shhagnum balticum, } \\
\text { Sphagnum lindbergii, Warnstorfia fluitans }\end{array}$ & $\begin{array}{l}\text { Epifibric Histosols; Spodic } \\
\text { Histic Turbic Cryosols (Arenic) }\end{array}$ \\
\hline \multirow[t]{2}{*}{ Kog } & \multirow[t]{2}{*}{62.3} & \multirow[t]{2}{*}{ Sand } & ridges & $1.7-2.3$ & not & 0.3 & $2064[36]$ & $6658[36]$ & $\begin{array}{l}\text { Pine-dwarf shrub-Sphagnum } \\
\text { Pinus sylvestris, Ledum palustre, Betula nana, Andromeda } \\
\text { polifolia, Chamaedaphne calyculata, Vaccinium myrtillus, } \\
\text { Vaccinium uliginosum, Sphagnum fuscum }\end{array}$ & $\begin{array}{c}\text { Ombric Fibric Histosols } \\
\text { (Hyperorganic) }\end{array}$ \\
\hline & & & fens & $1.0-1.5$ & not & - & 769-1274 [36] & $8865-10973[36]$ & $\begin{array}{l}\text { Sedge-Sphagnum } \\
\text { Carex rostrata, C. limosa, Eriophorum polystachyon, } \\
\text { Sphagnum majus, S. jensenii }\end{array}$ & Ombric Fibric Histosols \\
\hline
\end{tabular}




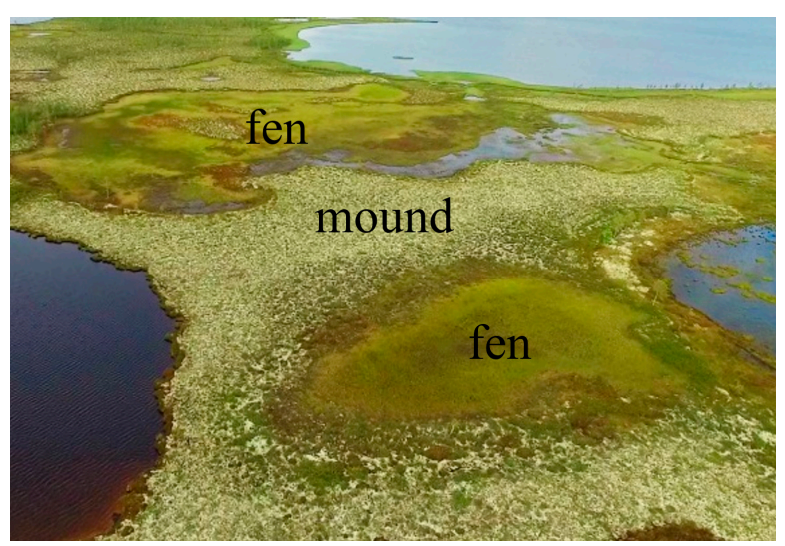

(a)

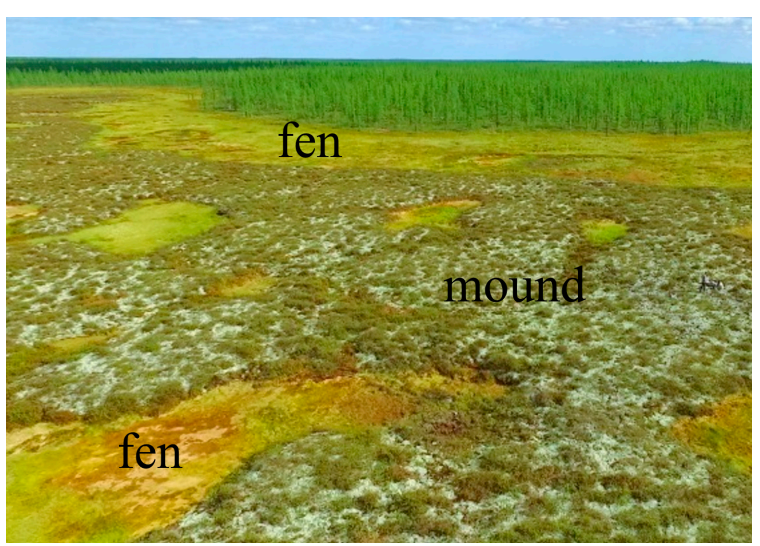

(b)

Figure 2. Landscapes of raised-mound bog: (a) Khanymey key site, northern taiga-the flat mound fenny-lake microlandscape on the flat interfluve; (b) Urengoy key site, forest-tundra-the gently convex fenny mound microlandscape.

The vegetation of studied mire types is predominantly oligotrophic (low in nutrient) which indicates ombrotrophic conditions. The mounds and polygons are covered by dwarf shrubs (Ledum ssp., Betula nana, Andromeda polifolia, Vaccinium ssp., Empetrum nigrum), lichens (Cladonia ssp., Cetraria, Ochrolechia), and mosses (Dicranum ssp., Polytrichum ssp., Sphagnum ssp.). The wet microforms contain moss-sedge communities (graminoids: Eriophorum russeolum, E. vaginatum, Carex rotundata, C. limosa; forbs: Menyanthes trifoliata, Comarum palustre; mosses: S. balticum, S. majus, S. lindbergii; and dwarf shrubs: Oxycoccus palustris). In the most southern site (Kogalym), the pine Pinus sylvestris is abundant on the ridges [37-39].

Within the selected points, sampling of the bog waters was performed, the depth of the permafrost was measured, the types of vegetation present were recorded, the soil was described, and the samples were collected for chemical analyses. The identification of the soil was given in accordance with the World Reference Base (WRB, 2014) [40]. Water sampling from the soil active layer was carried out in two ways: (1) Using the suction cup lysimeters $(95 \mathrm{~mm}$ long and $21 \mathrm{~mm}$ in diameter with a $2 \mu \mathrm{m}$ pore size) produced by SDEC company (France) that were installed at a depth of 30-15 cm below the moss layer; (2) on the permafrost boundary after digging a pit (the so-called stagnant supra-permafrost waters). At all sites, bog water samples were collected in thawed or frozen soils that belonged to the Histosols group (according to WRB 2014, i.e., having a peat thickness $>60 \mathrm{~cm}$ ). Details of the selected methods of water extraction were described previously [41].

Collected waters were immediately filtered in $30 \mathrm{~mL}$ of pre-washed PP Nalgene®flacons through single-use Minisart filter units $(0.45 \mu \mathrm{m}$ pore size, Sartorius, acetate cellulose filter). The first $20 \mathrm{~mL}$ of filtrate was discarded. Filtered solutions were divided into two parts: Acidified $(\mathrm{pH} \sim 2)$ with ultrapure double-distilled $\mathrm{HNO}_{3}$ for TE analyses and non-acidified for DOC, DIC, and anion analyses. The $\mathrm{pH}$ was measured in the field using a combined electrode with an uncertainty of $\pm 0.02 \mathrm{pH}$ units. DOC and DIC were analyzed using a Carbon Total Analyzer (Shimadzu TOC VSCN) with an uncertainty better than 3\% [42], for methodology. Major anion $\left(\mathrm{Cl}, \mathrm{SO}_{4}\right)$ concentrations were measured by ion chromatography (HPLC, Dionex ICS 2000) with an uncertainty of $2 \%$. Major cations (Ca, Mg, $\mathrm{Na}, \mathrm{K}), \mathrm{Si}$, and about 40 TEs were determined with an Agilent ce 7500 ICPMS with In and Re as internal standards and 3 various external standards. The SLRS-5 (Riverine Water Reference Material for Trace Metals certified by the National Research Council of Canada) was used to check the accuracy and reproducibility of each analysis [43]. Details of TE analyses in DOC-rich waters of western Siberia and reliability of certified samples measurements are described elsewhere [44,45].

A peat corer with Ti blades and a holder was used to extract the soil samples from the surface to the mineral layer (or the permafrost ice). For the measurement of the element concentrations, the peat soil samples were first processed in a clean room (class A 10,000) and then were digested in Teflon (Savilex, 
MN, USA) reactors ( $6 \mathrm{~mL}$ bi-distilled $\mathrm{HNO}_{3}, 0.2 \mathrm{~mL}$ ultrapure $\mathrm{HF}$, and $1 \mathrm{~mL}$ ultrapure $\mathrm{H}_{2} \mathrm{O}_{2}$ ) using a Mars 5 microwave digestion system (CEM, France). The major and trace element concentrations were measured by ICP-MS (Agilent 7500 ce) using a three-point calibration against a standard solution of known concentration.

To determine the peat growth rates, radiocarbon analysis was performed using a liquid scintillation method (Quantulus spectrometer-radiometer). Calibration of the radiocarbon age in the calendar was conducted using the OxCal 3 program. Temperature observations on the polygon and the fen in the southern tundra were carried out using an automatic monitoring system. The data were determined at a depth of $5 \mathrm{~cm}$ and were averaged over the 2 points in the fen, over the 2 observation points on the polygon, and over the 4 points within the mineral bank of the fen. The average daily temperatures were obtained by observation 12 times a day.

The data on the carbon and major element concentrations were analyzed with best fit functions based on the least-squares method with STATISTICA version 8 software (StatSoft Inc., Tulsa, OK, USA). Regressions and power functions were used to examine the relationships among the elemental concentrations, the microform, and the different hydrological regime. A criterion for significant dependence was that the determination coefficient was higher than $0.5\left(R^{2} \geq 0.5\right)$. The normality of data distribution was checked using the criterion of Kolmogorov-Smirnov separately for each site and for the full set of the data. Because data were not normally distributed, we used the non-parametric H-criterion Kruskal-Wallis test, and then, in case of significant differences $(p<0.05)$, we used the Wilcoxon-Mann-Whitney test. In these methods, a value of $p<0.05$ indicates that the differences in the values are important and are statistically significant. In contrast, a value of $p>0.05$ indicates that the differences in the values are not statistically significant. All graphics and figures were created using MS Excel 2010, MS Visio Professional 2016, and the GS Grapher 11 package.

\section{Results}

\subsection{Features of Key Site Bogs and Soil Identification}

Within the studied bogs, Histosols are the main soil type, and less often, Histic Entic Podzols, Histic Gleysols, and Histic Cryosols are found [40]. The southernmost KS, Kogalym, is located in the south of northern taiga and is confined to flat interfluves. The peat soils of the bogs were formed as a result of waterlogging by atmospheric waters. Groundwater did not affect the peat accumulation, as the considered KS is located at the upper level of the interfluve. Current bogs are represented by ridge-hollow-lake complexes. The soils of these bogs are Histosols. Dystric Ombric Fibric Histosols (Hyperorganic) are common on the ridges, and Dystric Ombric Fibric Histosols are found in the fens. There is no permafrost within the peat and underlying mineral deposits. On the ridges, the peat thickness varies from 1.7 to $2.3 \mathrm{~m}$, and in the hollows and fens it ranges from 1.0 to $1.5 \mathrm{~m}$. The underlying rocks are sands and sandy loams. The ridges of this key area are covered with pine-shrub phytocenoses, and in all other studied key areas, there are practically, no trees on the mound.

The KS Khanymey is located in the central part of the northern taiga. Here, bogs began to form around 9-10 thousand years ago. This was a carpet-type bogging, where peat accumulation occurred simultaneously in a variety of microrelief depressions. It was initially autonomous and was not formed under the water influx associated with the mesorelief. Dystric Hemic Cryic Histosols are usually found on mounds. Spodic Histic Turbic Cryosols (Albic, Arenic) and Histic Turbic Cryosols (Albic, Arenic) are less commonly found on mounds. Dystric Epifibric Endohemic Histosols are formed in the fens (Figure 3). These soils are confined to locally elevated areas or to lakeside slopes where the peat thickness becomes less than $40-60 \mathrm{~cm}$. The peat thickness ranges from 0.1 to $1.4 \mathrm{~m}$ on mounds and from 0.4 to $1.1 \mathrm{~m}$ in the fens or hollows. The permafrost lies at depths of $40 \mathrm{~cm}$ and deeper on the mounds, and the hollows (depressions) do not have permafrost to depths of several meters. Peat soils are underlain by sandy deposits. The peat growth rate in the fens is significantly higher than in the 
hollows. For example, peat has been growing in one fen at a rate of $0.54 \mathrm{~mm} /$ year (over the past 700 years) (Table 1), and in another fen at a rate of $0.96 \mathrm{~mm} /$ year (over the past 360 years). On the mounds, the peat growth rate is several times less. In one case, it was found to be $0.15 \mathrm{~mm} /$ year for 1850 years, and in another case, it was $0.28 \mathrm{~mm} /$ year for the last 1070 years.

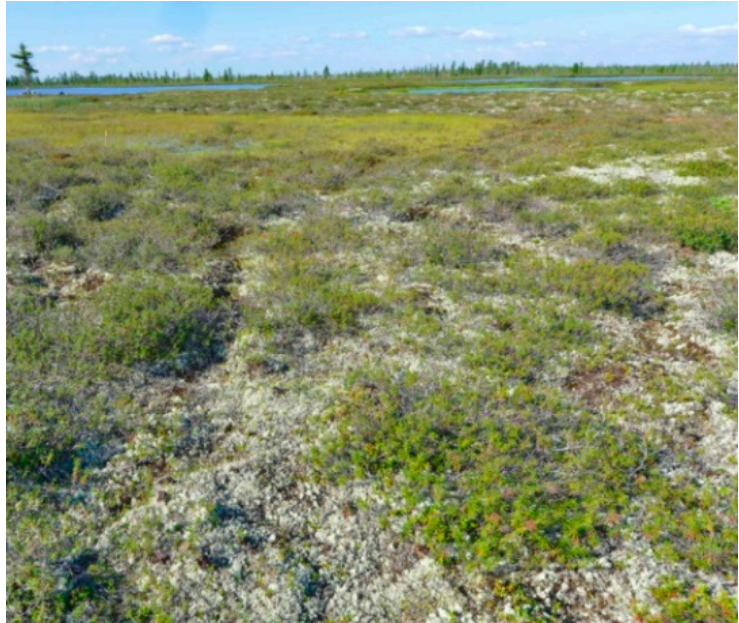

(a)

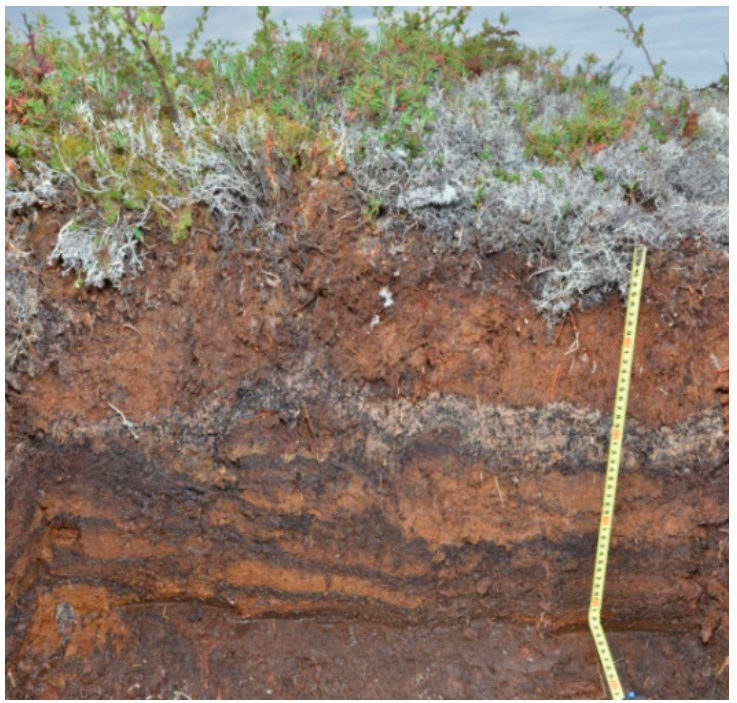

(c)

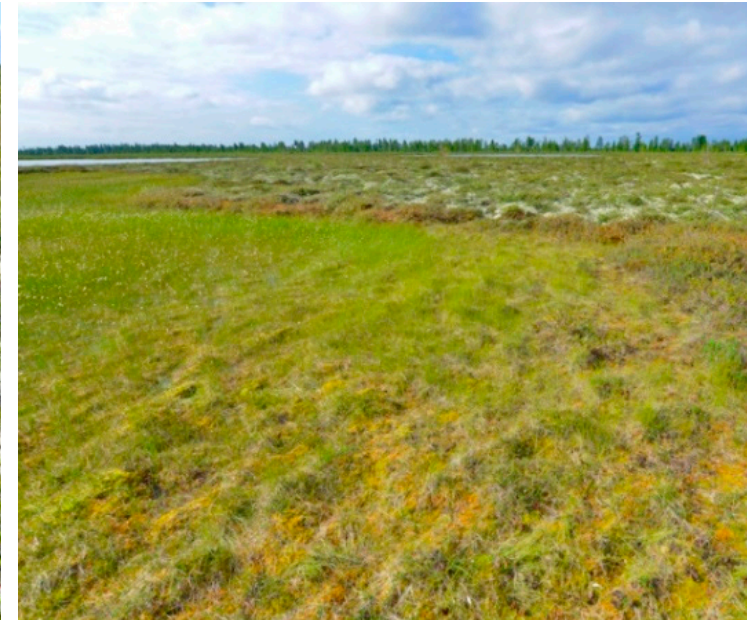

(b)

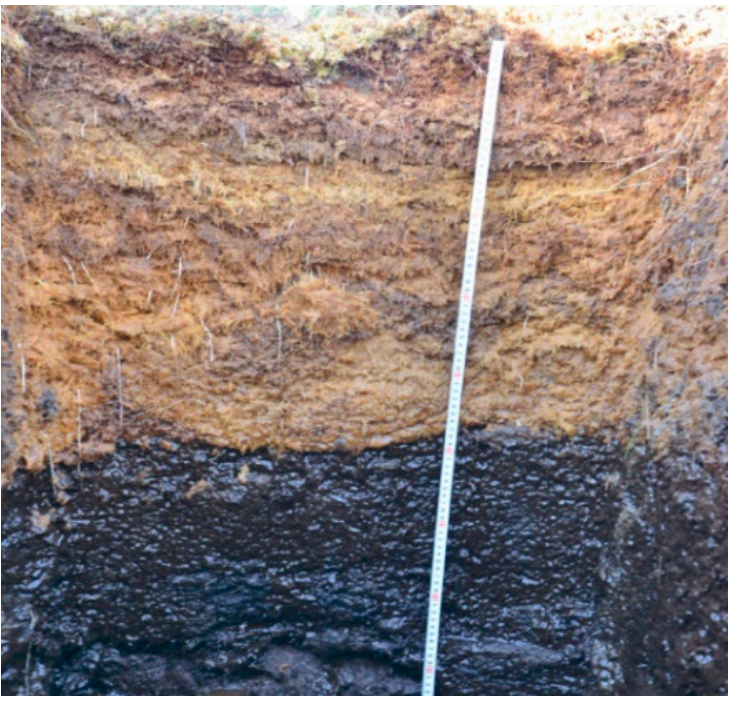

(d)

Figure 3. Plant communities and soils of the frozen bogs of the Khanymey site: (a) Moss-shrub-lichen community on the mound; (b) moss-sedge community of lakeside fen; (c) Dystric Hemic Epicryic Histosols; (d) Dystric Epifibric Endohemic Histosols. The soil of (c) correspond to the plant community of (a), and the soil of $(\mathbf{d})$ correspond to $(\mathbf{b})$.

In the forest tundra, two key sites were selected. The KS Pangody is located in the central part of the flat plain and is genetically similar to the previous sites. On the mounds, soils are represented mainly by Dystric Hemic Epicryic Histosols and much less often by Histic Reductaquic Turbic Cryosols (Loamic) and Histic Cryosols (Loamic). The active layer thickness (ALT) is $49 \mathrm{~cm}$ on average with a peat thickness from 0.2 to $1.3 \mathrm{~m}$. Dystric Epifibric Endocryic Histosols and, less commonly, Histic Reductaquic Turbic Cryosols (Loamic) are formed in the fens. Permafrost occurs at a depth of $82 \mathrm{~cm}$ on average, and the peat thickness varies from 0.3 to $1 \mathrm{~m}$. The underlying peat layers are represented by loamy deposits. 
The second key site (Urengoy) of the forest tundra is located on raised-mound bogs. At present, its central part is autonomous and flowing waters from the mineral slopes are intercepted by marginal fens. However, until the permafrost formation in the bogs, peat deposits increase under the influence of the waters flowing from the mineral slopes of the catchment. The thickness of the peat deposit is $2.0-2.5 \mathrm{~m}$ on the mounds and $0.3-1.2 \mathrm{~m}$ in the fens. The high thickness of peat is characteristic of bogs in trough, which were influenced by the waters of mineral slopes in the early Holocene. Soils on the mounds were diagnosed as Dystric Hemic Epicryic Histosols (Hyperorganic). On average, the ALT is $49 \mathrm{~cm}$ on the mounds and $98 \mathrm{~cm}$ in the fens. As the catchment area of the fens increases, the permafrost in it may fall to deeper than $2 \mathrm{~m}$.

The northernmost KS Tazovsky is confined to the polygonal bogs. Most of the peat in these bogs was formed in the first half of the Holocene under heteronomic conditions. At present, the central parts of the bogs are elevated relative to their edges and are not affected by flowing moisture from the slopes. Dystric Hemic Epicryic Histosols (Hyperorganic) and Dystric Murshic Hemic Epicryic Histosols (Hyperorganic) are common on the mounds, which have an average ALT is $41 \mathrm{~cm}$ and peat thickness varying from two to four meters. The underlying rocks are represented by loams. Dystric Fibric Cryic Histosols and Histic Reductaquic Cryosols (Clayic) are common in the fens. The average ALT in the fens increases to $65 \mathrm{~cm}$, and the peat deposit thickness ranges from 0.2 to $1.5 \mathrm{~m}$.

In general, it is evident from the presented data that the peat thickness within the fens is lower than on the adjacent elevated elements of the microrelief. On the contrary, the ALT is greater within the fens. The upper part of the peat deposits of the fens are represented by light peat with dominance of sphagnum and cotton sedge remains, including roots. The level of bog waters in the fens is usually located not lower than minus 10-15 cm. In the soils of the most convex mounds/polygons, the supra-permafrost waters are often absent or form a layer several centimeters thick at the bottom of active layer. This is also due to the higher water retention capacity of peat composing the mounds/polygons.

Based on literary sources [46-50], as well as our own data, the history of the development of raised-mound bogs of the northern taiga can be presented as follows: In the Subboreal and Atlantic periods, there was active peat accumulation. The initial surfaces of these Atlantic bogs were characterized by a relatively weak microrelief. These bogs were represented by fens, where the peats deposit properties did not significantly differ laterally across bogs. These were relatively flat eutrophic-mesotrophic bogs. At the beginning of the Subboreal period of the Holocene, they began to freeze (4.5 thousand BP), both in Western Siberia and in the north-west of European Russia. Peat accumulation slowed down a lot. Then, in the Subatlantic period (2.5 thousand BP-present), the permafrost began to thaw, thus forming the subsidences and fens; the surface subsided, and the mounds additionally rose, due to the formation of ice layers at the base of the peat deposit. The growth of mounds due to ice segregations often led to breaking and spreading of peat in thin layers. In places of peat spreading, the hollows and fens with low peat thickness were formed.

\subsection{Properties of Histosols Formed on Various Bog Microtopes}

In Histosols of the elevated microtopes (mounds/polygons), the total organic carbon (TOC) content $(40.3-55.2 \%)$ is slightly higher compared to in the fens $(39.8-53.7 \%)$. The soil profile shows a tendency of increased the TOC in the lower horizons, and especially, in the Dystric Hemic Cryic Histosols of the mounds or polygons. In general, the highest values of the TOC are characteristic of the Kogalym soils. The lowest concentrations of the TOC are observed in the Histosols of the KS Tazovsky. The complex of conditions in which soils are formed determines the acid reaction of the environment ( $\mathrm{pH} 3.0-3.9$ on the mound and $\mathrm{pH} 3.2-4.0$ in the fens). The content and distribution of the exchange bases is explained by their biogenic accumulation. Regardless of the microtope, the content of exchangeable cations increases with depth $\left(\mathrm{Ca}^{2+}\right.$ from 19 to $27 \mathrm{meq} / 100 \mathrm{~g}$ and $\mathrm{Mg}^{2+}$ from 7 to $18 \mathrm{meq} / 100 \mathrm{~g}$ ). There is no statistically significant difference between the soils of the two bog microtopes $(p>0.05)$. High values of hydrolytic acidity are noted with a predominance of large values in the Dystric Hemic Cryic Histosols of the elevated microtopes (mound/polygon) ( $p \leq 0.048)$. 
According to the degree of saturation of the soil-absorbing complex, the Histosols are characterized as unsaturated (12.8-28.6\% in mounds/polygons and $15.8-29.9 \%$ in fens). The results of the analysis indicate a low ash content (1.9-7.2\%), which generally corresponds to the content of ash in the peat. The highest values in individual cases can be traced in the soil of the fens $(p=0.012-0.023)$.

Histosols are characterized by unequal accumulation and distribution of elements $(\mathrm{Ca}, \mathrm{P}, \mathrm{K}, \mathrm{Mg}$, $\mathrm{Na}, \mathrm{Fe}, \mathrm{Al}, \mathrm{Sr}, \mathrm{Mn}, \mathrm{Cr}, \mathrm{Co}, \mathrm{Ni}, \mathrm{Cu}, \mathrm{Zn}, \mathrm{Cd}, \mathrm{Pb}, \mathrm{As}$, and $\mathrm{Sb}$ ). For some of them, statistically significant differences $(p<0.05)$ were identified for the soils of the two considered microtopes. For example, the concentrations of Fe (KS Khanymey), Ca, Co (KS Urengoy), and Mn (with the exception of KS Tazovsky) are higher in the soils of the fens compared with the mounds/polygons. Conversely, the highest values of $\mathrm{K}, \mathrm{Na}, \mathrm{Al}, \mathrm{Cu}$ (KS Tazovsky), Zn (KS Urengoy, Khanymey) are traced in the Histosols of the elevated microtopes. In addition, there are higher concentrations of $\mathrm{Mn}, \mathrm{Cr}, \mathrm{Co}$, which exceed those encountered in the Histosols of other boreal plains of northern Eurasia. This, in turn, is a characteristic feature of the Histosols of Western Siberia [51-55].

There is a high degree of depth variation in the element concentrations of the studied soils. Thus, in the Histosol of the polygons (KS Tazovsky), most of the elements (Ca, P, K, Mg, Na, $\mathrm{Al}, \mathrm{Sr}, \mathrm{Mn}$, $\mathrm{Cr}, \mathrm{Cu}, \mathrm{Zn}, \mathrm{Se}, \mathrm{Pb}, \mathrm{Cd}, \mathrm{Sb}, \mathrm{Cs}, \mathrm{B}, \mathrm{Ba}, \mathrm{La}$, Th, etc.) tend to accumulate in the upper part of the profile $(5-30 \mathrm{~cm})$, with the exception of $\mathrm{Fe}, \mathrm{Ni}, \mathrm{Co}$, and As, whose concentrations are higher at a depth of $30-50 \mathrm{~cm}$. On the contrary, in soils of the concave microtopes, the concentrations of most elements, except for $\mathrm{P}, \mathrm{Zn}, \mathrm{Mg}, \mathrm{Sb}, \mathrm{Co}, \mathrm{As}, \mathrm{Cd}$, and $\mathrm{Pb}$, are higher in the lower part of the soil profile. In the more southern site (KS Khanymey), the concentrations of $\mathrm{K}, \mathrm{Na}, \mathrm{Ni}, \mathrm{Cs}, \mathrm{Cu}, \mathrm{Cr}, \mathrm{Mo}, \mathrm{Zr}, \mathrm{Al}, \mathrm{Ti}, \mathrm{Ba}, \mathrm{Th}, \mathrm{V}$, and $\mathrm{Ce}$ accumulate to a greater extent in the deeper horizons of the soil profile of the mounds, and $\mathrm{Pb}$, $\mathrm{Zn}, \mathrm{Sb}, \mathrm{Mg}, \mathrm{Mn}, \mathrm{Cd}, \mathrm{Ca}, \mathrm{Co}, \mathrm{P}, \mathrm{Sr}$, and Fe accumulate on the surface. In the soils of the fens, almost all presented elements, with the exception of $\mathrm{B}, \mathrm{U}, \mathrm{As}, \mathrm{Se}, \mathrm{La}, \mathrm{Ce}$, and $\mathrm{V}$, exhibit higher values in the upper part of the profile.

\subsection{Hydrochemical Contrast of the Convex and Concave Microtopes}

Results of the application of the Wilcoxon-Mann-Whitney test for assessing the differences in mean values with SD of DOC, DIC, major and trace elements in bog waters of two dominant microtopes are listed in Table A1 (see Appendix A). The mean values given in the last three columns for the two dominant microtopes of all key sites showed that the of the majority of the element concentrations (except $\mathrm{Fe}$ ) in the bog waters are either approximately equal or higher by 1.5-2 times on the mounds. At the same time, according to the chosen statistical criteria, only a few parameters (specific conductivity (Cond), $\mathrm{pH}, \mathrm{SO}_{4}{ }^{2-}$, DOC, $\mathrm{Fe}, \mathrm{Ti}, \mathrm{V}, \mathrm{Cs}, \mathrm{Tb}$ and $\mathrm{Tl}$ ) depict significant differences $(\mathrm{p}<0.01)$ in their concentration between mounds/polygons and hollows/fens.

If we consider the differences within each key sites, then the most significant differences (in 29 parameters out of 55) in the microtopes occurs within the polygonal bogs of the Tazovsky KS. The concentrations of these parameters, except for the DIC, are higher in the bog waters of polygons. Within the ombrotrophic ridge-hollow raised bogs (KS Kogalym), differences were identified by 21 parameters, which turned out to be with higher values (except $\mathrm{Si}$ ) in the bog waters of the mounds. Within raised-mound bogs, the differences between microtopes were less pronounced. Thus, at the KSs Urengoy, Khanymey, and Pangody, significant differences were found for 13, 11, and 8 parameters, respectively.

In general, among all the considered parameters, the most significant (having statistical differences on three or more sites) in the mounds/polygons and hollows/fens were the specific conductivity (significant differences for all KS), DOC (except KS Urengoy), $\mathrm{SO}_{4}{ }^{2-}$ (except for the KSs Kogalym and Pangody), Al (except for the KS Pangody), V (except for the KS Khanymey), Mn (except for the KSs Kogalym and Khanymey), and some rare earth elements (REEs) (La, Ce, Nd) (except for the KSs Pangody and Khanymey). The values of $\mathrm{pH}, \mathrm{Ca}, \mathrm{Mg}, \mathrm{Fe}, \mathrm{Si}, \mathrm{Cu}, \mathrm{Sb}$ and REEs (Pr, Eu, Tb, Dy, Er, $\mathrm{Yb}$ ) in bog waters showed differences between microtope types in only two key sites (Figure 4). The $\mathrm{Cl}^{-}, \mathrm{K}$, $\mathrm{Li}, \mathrm{Na}, \mathrm{Cr}, \mathrm{Ga}, \mathrm{Mo}, \mathrm{Zn}, \mathrm{Ba}, \mathrm{Pb}, \mathrm{Hf}$, and $\mathrm{W}$ concentrations turned out to be indifferent to the microtope type and did not show significant differences within all key sites. 

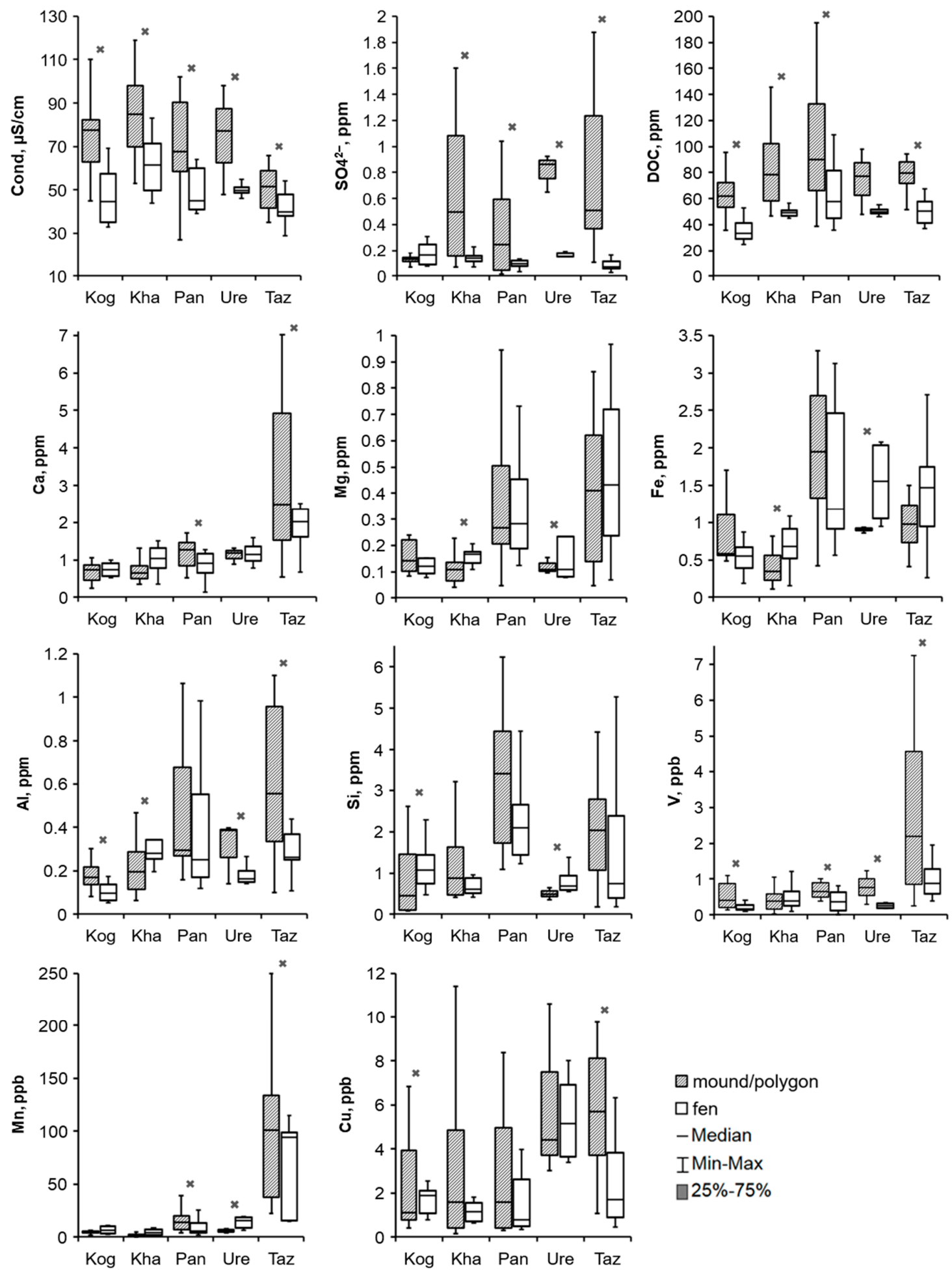

Figure 4. Comparison of the bog water hydrochemical parameters of the different microtopes with significant differences $(p<0.05)$ at two or more key sites: Taz-Tazovsky; Ure-Urengoy; Pan -Pangody; Kha-Khanymey; and Kog-Kogalym. An asterisk represents significant differences between microtopes, $p<0.05$.

A comparison over the key sites of mean values $(\mathrm{M} \pm \mathrm{SD})$ of bog waters showed statistically significant higher the DOC, Cond, $\mathrm{SO}_{4}{ }^{2-}, \mathrm{Ca}, \mathrm{Ti}, \mathrm{Cu}, \mathrm{V}, \mathrm{Mn}$ and REEs values on the mounds relative to the fens by a factor $1.5 \pm 0.2$. The $\mathrm{pH}$ in most cases turned out to be similar with slightly higher values in the waters of the fens. Only at the KSs Khanymey and Urengoy, the fens were found to be 
significantly $(\mathrm{p}<0.03)$ less acidic then mounds, namely $3.8 \pm 0.2$ versus $3.5 \pm 0.3$ in the waters of the KS Khanymey, and $4.6 \pm 0.3$ versus $4.1 \pm 0.2$ in the waters of the KS Urengoy. In terms of the specific conductivity, the waters of the KS Khanymey stood out, showing $87.1 \pm 23 \mu \mathrm{S} / \mathrm{cm}$ within the mounds and $61.6 \pm 14 \mu \mathrm{S} / \mathrm{cm}$ in the fens. The difference in mean DOC values between microtopes was the largest within the KS Khanymey (32 ppm) and the smallest in the KS Urengoy (24 ppm). The highest DOC concentration was found in the bog waters of the KS Pangody, which was $99 \pm 45.9 \mathrm{ppm}$ on the mound and $68.8 \pm 36 \mathrm{ppm}$ in the fens. In the bogs of the KS Tazovsky, the Ca concentrations were the highest and reached $3.17 \pm 2.2$ on the polygons and $2.26 \pm 1.4 \mathrm{ppm}$ in the fens. True-dissolved and colloidal forms of iron showed higher concentrations in the waters of the fens at three sites (KS Khanymey, Urengoy). At the Kogalym and Urengoy sites, the Si concentration showed sizeable difference between microtopes, and in both cases, it was the highest in fens versus mounds, namely $1.17 \pm 0.61$ versus $0.84 \pm 1.04(\mathrm{p}<0.048)$ and $0.82 \pm 0.38$ versus $0.49 \pm 0.1(\mathrm{p}<0.046)$, respectively.

In the bog waters of the two key sites Khanymey and Tazovsky, dissolved $\mathrm{CO}_{2}$ and $\mathrm{CH}_{4}$ concentrations (Mean \pm SD) were measured. In the bog waters of the mounds and the fens of the KS Khanymey, the concentrations of $\mathrm{CO}_{2}$ were $1319 \pm 1011$ and $793 \pm 274$ ppm, respectively. In the bog waters of the polygons and the fens of the KS Tazovsky, the $\mathrm{CO}_{2}$ concentrations were $1056 \pm 891$ and $801 \pm 417$ ppm, respectively. The $\mathrm{CH}_{4}$ concentrations in the bog waters of the mounds and the fens of the KS Khanymey were $87 \pm 127$ and $69 \pm 94$ ppm, respectively. Within the KS Tazovsky, these values were $0.32 \pm 0.58$ and $17.8 \pm 40.6 \mathrm{ppm}$ for the polygons and the fens, respectively.

Parameters of bog waters vary within the Histosols profiles. These parameters change with different rates in the depths of the soil profile in the mounds and fens. To assess the differences in the contrast of the soil profiles of the mounds and fens, we used three parameters of the bog waters (Cond, $\mathrm{pH}$, and DOC). The data is given below for all key sites. For this, we considered the data obtained from the suction cup lysimeters installed in the upper part of the profile in the range of $10-50 \mathrm{~cm}$ for both mounds/polygons and fens. On the mounds/polygons, the $\mathrm{pH}$ increased downward the soil profile with an average rate of 0.04 units $/ 10 \mathrm{~cm}$. In the fens, the rate was 0.13 units $/ 10 \mathrm{~cm}$. That is, based on the $\mathrm{pH}$ values, the soil profiles of the fens were three times more contrasting than in the mounds. The DOC concentrations changed by $6.3 \mathrm{ppm}$ on the mounds/polygons and $10.5 \mathrm{ppm}$ on the fens for every $10 \mathrm{~cm}$ of soil profile. Thus, the soil of the fens was 1.7 times more contrasting than the soil of the mounds. The soil conductivity profile of the hollows was, on average, two times more contrasting than the mounds/polygons. On the mounds, the Cond increased with a value of $3.9(\mu \mathrm{S} / \mathrm{cm}) / 10 \mathrm{~cm}$ profile, and in hollows, by a value of $7.89(\mu \mathrm{S} / \mathrm{cm}) / 10 \mathrm{~cm}$.

For $\mathrm{pH}$, the dissolved oxygen, electrical conductivity, and macro- and trace-elements of bog waters, the changes at different hydrological regimes were considered. This work was carried out for bogs at the KS Tazovsky which had the greatest surface heterogeneity and large elevation differences, enabling the microtopes with different hydrological regimes to be well identified (Figure 5). All measured points were arranged in the following order according to the hydrological regime (see Figure A1 in Appendix B): Lower parts of the fens with a watercourse (4) $>$ large fens without a watercourse (3) $>$ degraded and flooded polygons and small cracks between polygons (2) > polygons occupying elevated dry positions (1). The dwarf shrubs and lichens grow only on polygons (1). Positions (2) and (3) are characterized by the dominance of sedges and sphagnum mosses. In the position (4), the cottongrass-sphagnum community is developed with a large share of Comarum palustre.

In order to examine differences in the concentrations of elements in bog waters with different hydrological regimes, we first ran the Kruskal-Wallis test and then the Wilcoxon-Mann-Whitney pair test (see Table A2 in Appendix A). According to the chosen statistical criteria, most parameters of the bog waters in fens with a watercourse (with hydrological regime 4) were found to be largely $(\mathrm{p}<0.05)$ different from the values in other flowing waters. At the same time, the Cond, $\mathrm{DOC}, \mathrm{SO}_{4}{ }^{2-}, \mathrm{Al}, \mathrm{Ti}, \mathrm{V}$, $\mathrm{Cr}, \mathrm{Cu}, \mathrm{Ga}, \mathrm{Sr}, \mathrm{Nb}, \mathrm{Mo}, \mathrm{Cd}, \mathrm{Cs}, \mathrm{Ba}, \mathrm{Th}, \mathrm{U}$, and almost all REEs exhibited a clear trend of decreasing values $\left(0.63<R^{2}<0.97, p<0.05\right)$ from bog water polygons occupying elevated dry positions to the lower parts of the fens with a watercourse (Figure 6). 


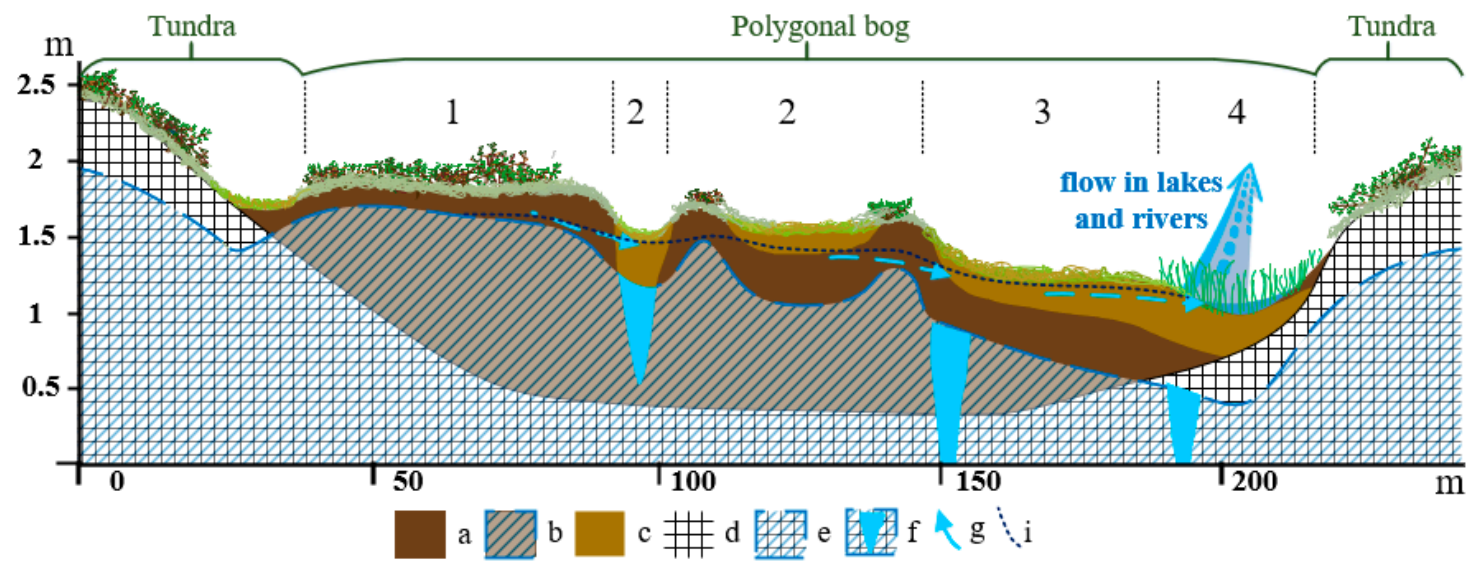

Figure 5. Microtopes of the polygonal bog with a different hydrological regimes of the key site (KS) Tazovsky (Taz). Legend: 1-polygons of elevated dry positions; 2-degraded and flooded polygons and small cracks between polygons; 3-large cracks and fens without a watercourse; 4-lower parts of the fens with a watercourse; a-medium degree of peat decomposition (Hemic); b-permanently frozen peat; c-low degree of peat decomposition (Fibric); d-loamy deposits; e-permanently frozen loamy; f-ice in the crack; g-direction of soil waters transport; i-level of bog waters.

Conversely, a clear statistically significant trend of increasing concentration $\left(0.56<\mathrm{R}^{2}<0.98\right.$, $\mathrm{p}<0.05$ ) was observed for the $\mathrm{pH}$, dissolved $\mathrm{O}_{2}, \mathrm{Cl}, \mathrm{Li}, \mathrm{Na}, \mathrm{Mg}, \mathrm{Mn}, \mathrm{Zn}$, and $\mathrm{Co}$ in the following order: Polygons occupying elevated dry positions $>$ degraded and flooded polygons and small cracks between polygons $>$ large cracks and fens without a watercourse $>$ lower parts of the fens with a watercourse (Figure 7). Concentrations of DIC, $\mathrm{Ca}, \mathrm{K}, \mathrm{Fe}, \mathrm{Si}, \mathrm{As}, \mathrm{Zr}, \mathrm{W}, \mathrm{Tl}$, and $\mathrm{Pb}$ did not exhibit any statistically significant trend $\left(R^{2}<0.5\right)$.
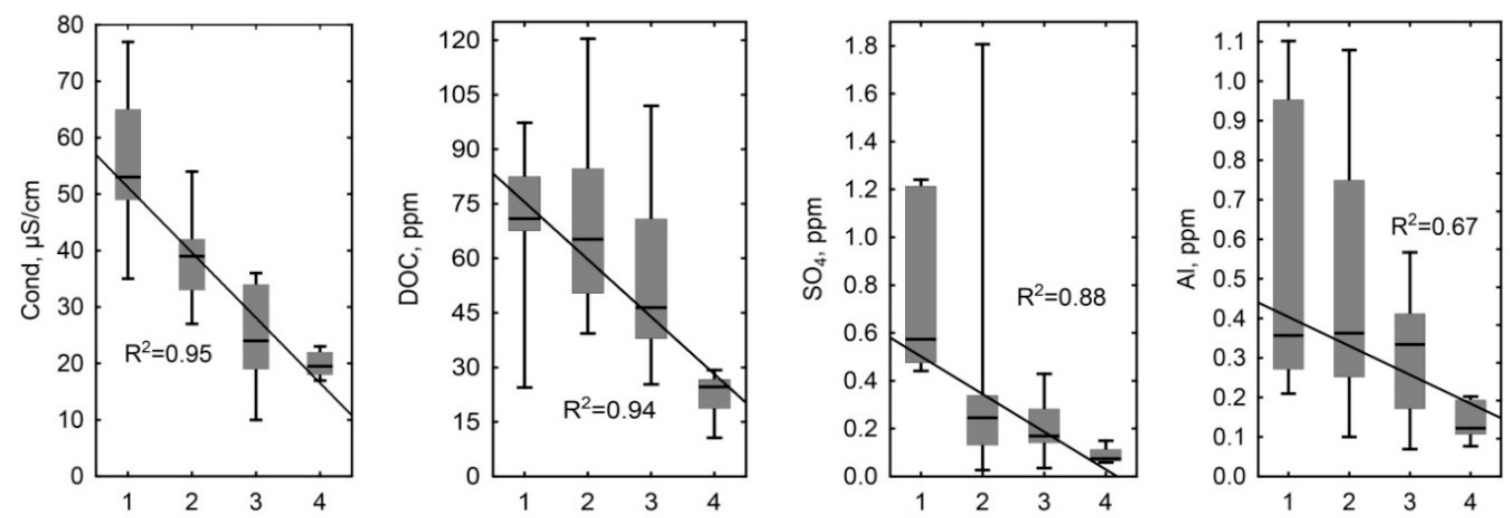

Figure 6. Cont. 

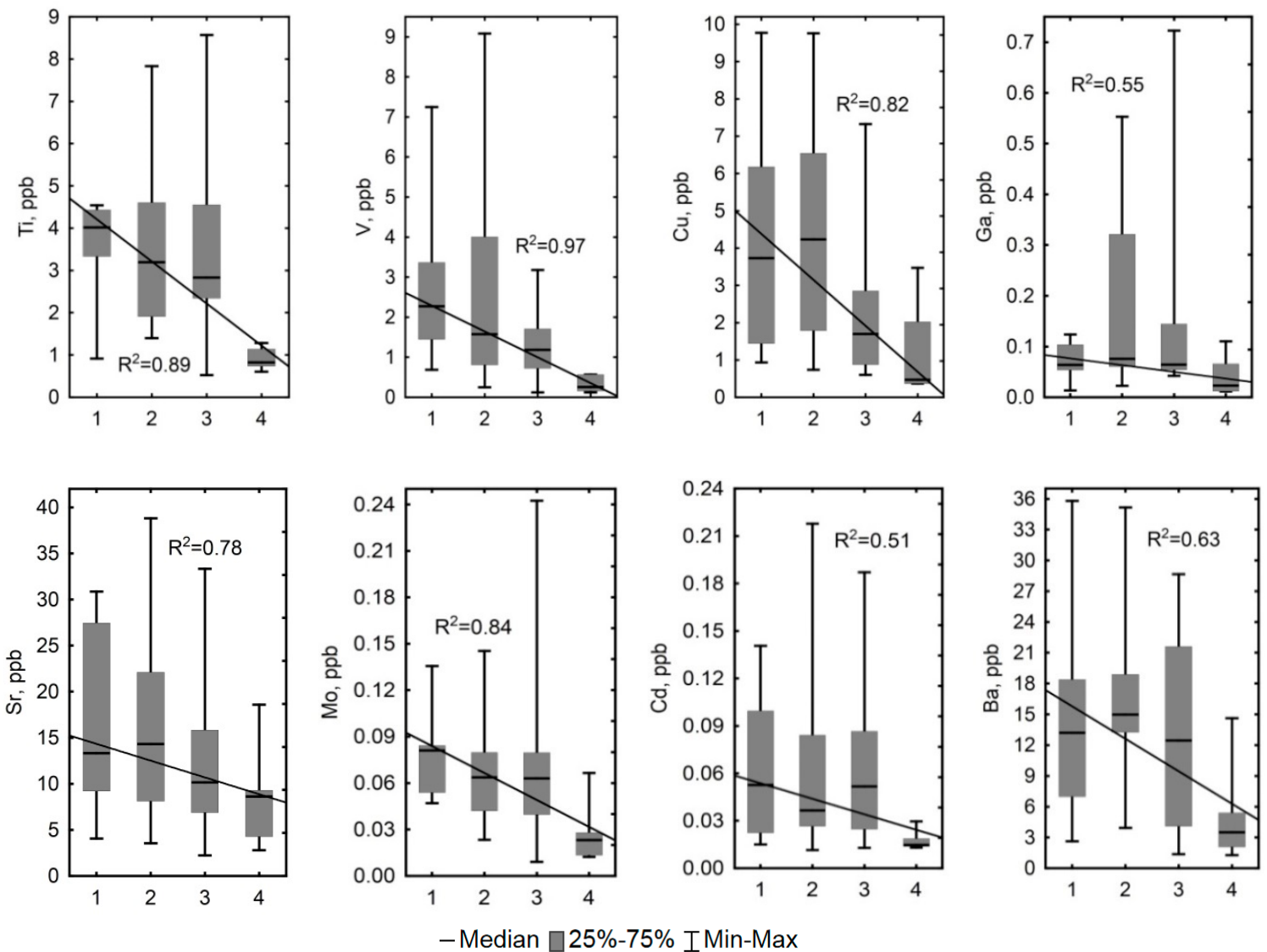

Figure 6. Some chemical parameters exhibited a clear trend in decreasing values $\left(0.63<\mathrm{R}^{2}<0.97\right.$, $p<0.05$ ) in bog waters of the KS Tazovsky (Taz) microtopes with different hydrological regime: 1-polygons occupying elevated dry positions; 2 - degraded and flooded polygons and small cracks between polygons; 3 -large cracks and fens without a watercourse; 4 -lower parts of the fens with a watercourse. The solid line is a linear fit to all data with the regression equation given on each graph. It should be noted that the categories (1-4) are becoming increasingly wet from left to right.
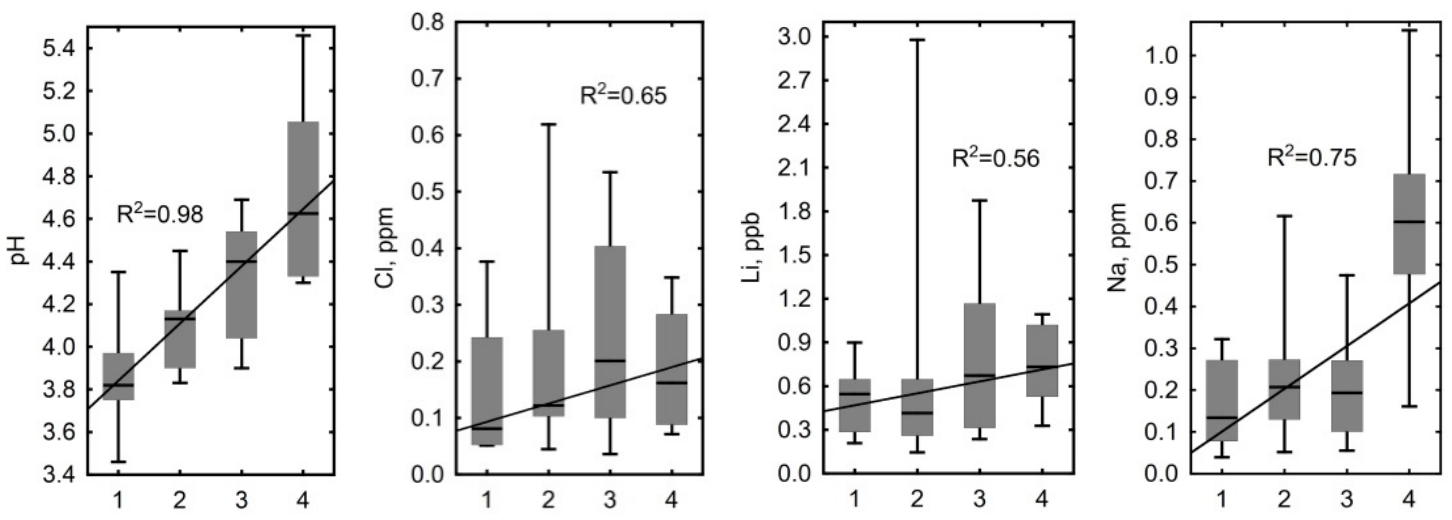

Figure 7. Cont. 

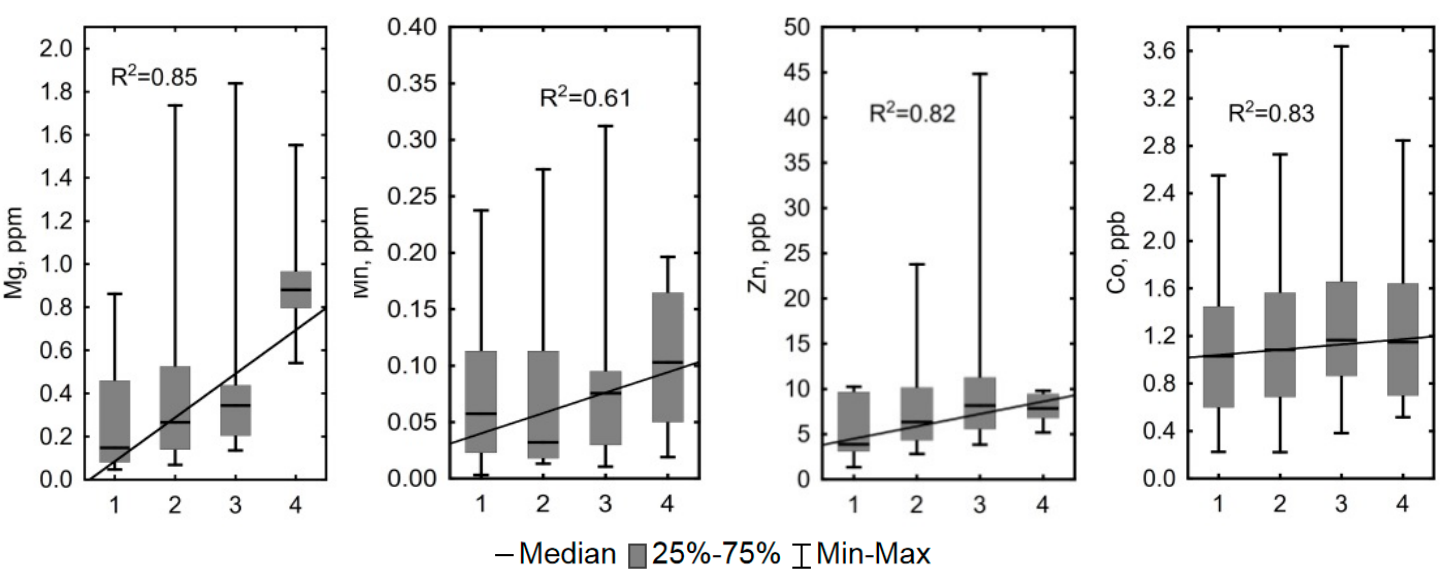

Figure 7. Concentrations of $\mathrm{Cl}, \mathrm{Li}, \mathrm{Na}, \mathrm{Mg}, \mathrm{Mn}, \mathrm{Zn}, \mathrm{Co}$ and $\mathrm{pH}$ values showed a clear statistically significant trend of increasing concentration $(0.56<\mathrm{R} 2<0.98, p<0.05)$ in the bog waters of the KS Tazovsky (Taz) microtopes with different hydrological regimes: 1 -polygons occupying elevated dry positions; 2-degraded and flooded polygons and small cracks between polygons; 3-large cracks and fens without a watercourse; 4 -lower parts of the fens with watercourse. The solid line is a linear fit for all data with the regression equation given on each graph. It should be noted that the categories (1-4) are becoming increasingly wet from left to right.

\section{Discussion}

\subsection{Influence of Hydrological and Thermal Regimes of Different Microtopes on the Bog Water Properties}

Differences between the convex (mounds, polygons) and concave (hollows, fens) landforms create catenary heterogeneity associated with their hydrological regimes $[2,56,57]$. In our work, studies were carried out during baseflow period (in the middle of August), which is characterized by an ALT increase of peat soils in frozen bogs. It is during this period that the frozen bogs have the greatest influence on the hydrochemistry of the surface waters of wetland watersheds. During the flood period in spring, water runoff occurs over the surfaces of still frozen bogs. Batuev [56] pointed out that the ratio between the moisture from thawing peat deposits on the mounds, gravitational moisture from the depletion of reserves in the fens, and precipitation to the formation of a minimum flow is 10:60:30 [56]. Taking into account that the share of fens (including hollows) accounts for 30\% of the bog area and the share of mounds is $70 \%$, it turns out that fens/hollows provide 14.3 times more water than mounds. Respectively, the water residence time in peat mounds is at least an order of magnitude longer than that in the fens/hollows.

In the spring, the hollows and fens receive melted snow which is accumulated there over the winter, and in the summer they receive rainwater. The suprapermafrost runoff from the mounds practically does not participate in the replenishment of the fens/hollows with water. In contrast, the mounds and polygons receive water essentially via snowmelt in spring. As a result, the fens and hollows are essentially responsible for delivering water, organic carbon, and solutes to the adjacent rivers and lakes. For the baseflow period, up to $80 \%$ of the bog watershed is drainless [2], that is, mounds and polygons do not provide any supra-permafrost waters in the bogs. Respectively, the gravitational moisture is either absent or has an extremely low filtration rate. The mounds and polygons are therefore essentially controlled by water evaporation, leading to an evaporative concentration of DOC and other solutes within the soil profile. This mechanism additionally increases the differences between mounds and hollows.

The noted differences are due to the fact that more snow accumulates in hollows and fens in spring, leading to higher water reserves. However, in our opinion, the main reasons lie in the hydrophysical properties of peat soils of mounds and hollows. Accordingly, data on filtration parameters in [2] for fens indicate that already at a depth of $23 \mathrm{~cm}$ from the average surface of the fen, the filtration coefficient drops 650 times (from 65 to $0.1 \mathrm{~cm} / \mathrm{s}$ ). In the zone of ombrotrophic ridge-hollow raised bogs, 
the coefficients of horizontal water loss are reduced by a factor of $2-5$ within the $70 \mathrm{~cm}$ profile. The bulk density of the mesotrophic and eutrophic peat composing the mounds and polygons is 2.5-11 times higher than the density of oligotrophic peat forming the fens and hollows [58].

Considering that peat in the lower part of hollows and fens is often similar in terms of physical properties to the peat of polygons and mounds (mesotrophic and eutrophic peat is often deposited in hollows in an inert hydrological zone), we can assume that the peat on the mounds and polygons is 2-10 times more dense, it has 2 to 5 times lower rate of water loss and tens of times lower filtration coefficients. These provide extremely slow movement of water on the mounds or polygons and increase the residence time of solutes in these microtopes. Accordingly, more concentrated soil solutions are formed within the mounds and polygons. The last statement is well supported by previous studies $[21,25,59]$, and is also illustrated by field data from the Tazovsky key site in the southern tundra. Due to the polygonal bogs having the greatest surface heterogeneity and large elevation differences, the microtopes with different hydrological regimes follow the order: Polygons > subsidences, cracks $>$ hollows/fens without watercourse $>$ fens with watercourse. In this direction, the values of electrical conductivity, $\mathrm{pH}, \mathrm{DOC}$, and macro- and trace-elements were determined for several such bogs. It can be clearly seen that with hydrological regime change in order of water flow increasing, the values of Cond, DOC, and some elements (Figure 6) decreased. In contrast, the values of $\mathrm{pH}$, and concentrations of dissolved $\mathrm{O}_{2}$ and some elements that are mobile in acidic environments (Figure 7) increased.

According to Batuev [60], the catchment area of the hollows and the fens ranges from $1000 \mathrm{~m}^{2}$ to $1.2 \mathrm{~km}^{2}$. It is obvious that the amount of water passing through the permafrost runoff will differ very significantly in the soils of different hollows or fens. That is, the degree of peat leaching will vary, while the residence time of the water will depend on the length of streamline. Therefore, the result will be composed of two components: (a) As the water moves along the streamline, the residence time of the water and accordingly, the amount of leached substances will increase; $(b)$ as the water moves along the streamline, the degree of flushing of the peat will increase, so the amount of incoming substance will decrease. It should be noted that the lateral drain in the hollows also leads to the vertical differentiation of parameters. On the polygons and mounds, sizeable leaching of the uppermost part of the peat soil occurs in spring.

To confirm these conceptual mechanisms, experiments with the $\mathrm{NaCl}$ tracer were carried out in the bogs of the southern tundra and northern taiga. The data obtained on water infiltration parameters of the hollows and permafrost subsidences demonstrate that water moves an order of magnitude faster in various depressions compared to polygons and mounds. The rate of water movement in the permafrost crack of the southern tundra polygonal bog was found to be $39 \mathrm{~cm} /$ day ( 35 meters in 3 months). It should be noted that the water movement in the crack with the highest speed occurred essentially within the surface layer of $10-15 \mathrm{~cm}$. The rate of water discharge on the slope fen that outputs water from the bog was found to be $86 \mathrm{~cm} /$ day $(77.4$ meters in 3 months). In the northern taiga flat mound bog, the rate of salt diffusion on the slope of the bog was $8.5 \mathrm{~cm} /$ day, that is, about $8 \mathrm{~m}$ over the three warm months.

The indicated microtopes also differ in the thermal regime, which can affect peat leaching. Thus, it was shown that in the subarctic catchment, the DOC export is maximal among the cotton grass fens, and its productivity is twice as high as in the sphagnum bogs [26]. The fens have large reserves of heat, the permafrost there is always deeper or even absent, and, accordingly, the seasonal freezing is much shorter (Figure 8) than that on the adjacent polygons. This was confirmed by both our field measurements in Tazovsky (the mean annual temperature of peat at a depth of $5 \mathrm{~cm}$ is equal to $-1.9^{\circ} \mathrm{C}$ in mounds and $+1.9^{\circ} \mathrm{C}$ in hollows) and the observations of other researchers $[18,61]$.

In the Nadym region (discontinuous permafrost zone), the mean annual temperatures of mounds and hollows are 1.0 and $1.6^{\circ} \mathrm{C}$, respectively [62]. Novikov et al. [2] pointed out that for a year with a $50 \%$ flow probability, the average annual temperature of the peat at a depth of $20 \mathrm{~cm}$ is $3{ }^{\circ} \mathrm{C}$ more in the fens/hollows than on the mounds. However, the maximum temperatures in hollows in summer 
are often less than on adjacent mounds [63]. A significant warming effect on small hollows is caused by snow accumulating in the depressions between the mounds which protects them from winter freezing [64]. In winter, the soil of the convex microtopes is very cold, and the temperatures at the same depths are several degrees lower in the mounds/polygons than in the fens/hollows $[63,65]$. It can be concluded that all fens and hollows are generally warmer than mounds and are divided into two groups: (1) Shallow hollows are warmer due to accumulated snow in winter and colder in summer; (2) fens with a large catchment area are warmer in summer and winter, due to both the higher power of snow insulation and the introduction of heat with the ground water flow, as well as with the surface spring runoff. If we consider the entire active horizon, then in the fens/hollow, the conditions of seasonal warming contribute to a greater accumulation of heat than in the mound and this, in our opinion, determines the deeper position of permafrost for the fens/hollow in the summer period.

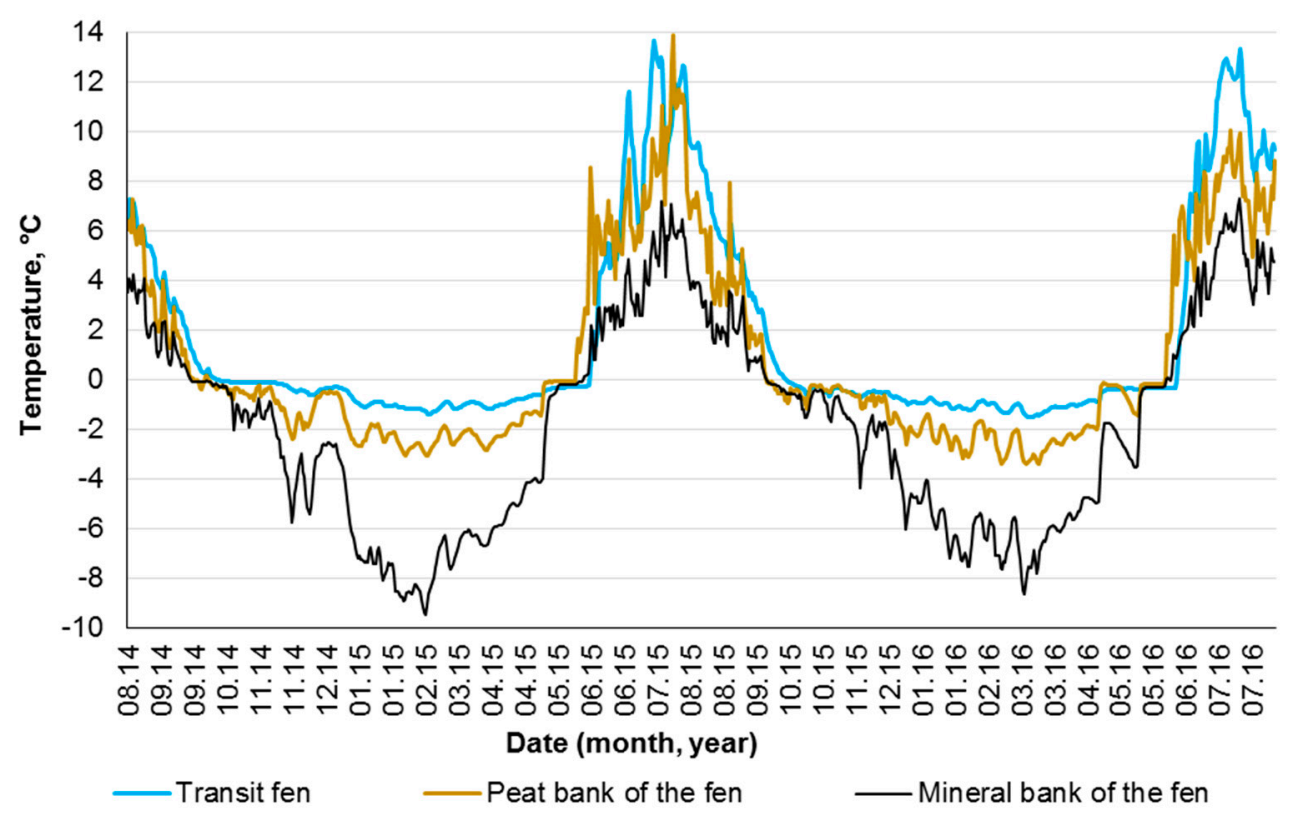

Figure 8. Soil temperature changes at a depth of $5 \mathrm{~cm}$ in the transit fen and bank of the fen. The fen is located on the edge of the polygonal bog within the KS Tazovsky in the southern tundra.

\subsection{Other Factors Determining Major and Trace Element Concentrations in the Bog Water of} Different Microtopes

The data collected in this study demonstrate that higher concentrations of DOC and some elements are observed in the bog water of mounds compared to that of hollows or fens (Table A1 in Appendix A). In addition to the different hydrological connectivity, evaporative concentration mechanism and the residence time of solutes in mound/polygons compared to hollows/fens, clay horizons underlying peat can affect the content of the DOC and related elements. It was hypothesized that the soluble DOC retention by clay horizons is the main regulator of the DOC level in rivers of a large latitudinal transect WSL [66]. The gradient of increasing of the DOC concentration to the north can be explained by the DOC-absorbing clay horizon that may be frozen in the north [67]. The latter authors suggested that the DOC in northern, permafrost-affected tributaries of the Yenisey River is less biodegradable (and thus better preserved during its transport from the soil to the river) than that in southern tributaries. If true, the lower DOC concentrations in the concave relative to the convex microtopes observed in the present study are due to DOC adsorption on unfrozen mineral layers (silt, clays) located below the peat horizon in depressions, which have a much deeper position of the ALT than the mounds. This mechanism can be tested by comparing the lithogenic element concentration in contrasting microtopes. Thus, the $\mathrm{Sr}$ content, which is considered an indicator of mineral sources in the surface waters [68,69], is highly similar between the mounds/polygons and the hollows/fens or even higher in mounds. The lack of a 
link between the Sr concentration and the ALT position within the peat-silt/clay profile suggests that the underlying minerals do not participate in feeding the bog waters by lithogenic elements.

Considering that the mineral part is frozen, and the concentrations of a number of lithogenic elements (Al, V, Li, Cr, Sr, REEs, Nb, Zr, Hf, Th, which correlate with Si) in the bog waters of the mounds is higher than in the fens/hollows, their most likely source is aeolian (long-range) dust deposits. The presence of aeolian dust deposits throughout the territory may lead to the incorporation of solid atmospheric particles into the moss biomass [7]. Recent studies of boreal bogs in Western Siberia have shown the presence of a wide spectrum of minerals in the atmospheric-dust particles of peat deposits [70]. Their deposition has been particularly enhanced by anthropogenic influences over the last century [71]. Therefore, the maximum dust stocks are confined to the upper parts of the peat deposits, which is confirmed by the distribution of chemical elements in the peat columns [72]. A significant contribution of atmospheric influences on the formation of springtime river fluxes of many metals has been shown at the study of snow [73]. In the snow, alumino-silicate minerals were found associated with desert and semi-desert regions of Central Asia. Snow accumulates more in the fens and hollows, therefore, more winter dust deposition per unit area is observed in the fens. In the summer season, the dust should better accumulate on mounds and polygons, as their vegetation is higher and is represented by dwarf shrubs and lichens, the shape of which is ideal for a dust capture. The dust fall is likely to be higher in the summer period, since the fields are plowed at this time in the south, therefore, the mounds receive more dust from the atmosphere, which ultimately affects the elemental composition of the bog waters. Moreover, the concentration of elements that likely originated from the silicate matrix ( $\mathrm{Al}, \mathrm{Si}, \mathrm{Fe})$ in the fens/hollows did not exceed that in the mounds. Taking into account that the position of the permafrost boundary is much closer to the mineral substrate in the concave microtopes compared to the mounds, this strongly suggests a lack of element leaching from the underlying mineral matrix. The conclusion that the peat chemical composition is not associated with the underlying mineral horizon, but with the composition of atmospheric depositions was also made on the basis of a geochemical analysis of peat and peat-forming plants [74].

Organic and organo-Fe-Al colloids also determine the behavior of most elements in waters with a high content of humic acids and a low total amount of dissolved particles in the permafrost zone of Western Siberia $[44,45]$. The behavior of many major elements and TEs in bog water is likely to follow that of $\mathrm{DOC}, \mathrm{Fe}$, and $\mathrm{Al}$ as main colloidal carriers. As a result, $\mathrm{Fe}$ and $\mathrm{Al}$ concentrations correlated with many TEs such as $\mathrm{Ti}, \mathrm{V}, \mathrm{Cr}, \mathrm{Co}, \mathrm{Ni}, \mathrm{As}, \mathrm{Sr}, \mathrm{Zr}, \mathrm{Nb}$, REEs, Hf, and Th. The lack of correlation of $\mathrm{K}$, $\mathrm{Rb}, \mathrm{Mn}, \mathrm{Ba}, \mathrm{Mo}, \mathrm{W}, \mathrm{Zn}, \mathrm{Pb}, \mathrm{Cd}, \mathrm{Cs}$, Sb with $\mathrm{DOC}, \mathrm{Fe}$ or $\mathrm{Al}$ can be explained by the specificity of these elements. In particular, the content of $\mathrm{K}, \mathrm{Rb}, \mathrm{Mn}, \mathrm{Cu}, \mathrm{Ba}$ is controlled by the moss growth [55], and $\mathrm{Zn}$, $\mathrm{Cd}, \mathrm{Pb}, \mathrm{Sb}, \mathrm{Tl}$ are delivered to the surface by atmospheric deposition on moss surface followed by incorporation into peat.

The mounds have a greater phytomass supply than fens (Table 1), especially at the expense of root systems of the dwarf shrubs. It has been shown that the aboveground biomass growth leads to an increase the DOC concentrations in the water flow passing through the plant litter and the live plants [75,76]. Therefore, a larger phytomass supply of the mounds [77] contributes to the carbon enrichment of bog waters of the mounds compared with the fens. The plant productivity is also higher on mounds than in fens [77], however, the peat accumulation rate on mounds is lower (Table 1). This is due to a more active peat decomposition, including the role of lichens [78], which slow down peat accumulation and are absent in the fens. The dwarf shrubs predominate on the mounds where decompose more intensely than sphagnum mosses absolutely dominant in the fens [79]. Constant over-wetting of fens also inhibit peat decomposition [80,81]. This means that during the decomposition of plant residues on the mounds, a greater amount of carbon is lost through the carbon dioxide emissions and leaching into the bog waters. The release of plant exudates also affect the amount of the DOC in the bog waters [82]. On the mounds, the underground organs of dwarf shrubs constitute the bulk of phytomass [77]. The dwarf shrubs produce more escudates with greater lability than sphagnum mosses $[83,84]$ prevailing in mass in the fens. Therefore, the input of exudates should enrich 
the bog waters of the mounds with carbon more than the fens. The lower DOC concentrations in fens water may also be associated with more active decomposition of organic compounds here. It has been shown that dissolved organic matter in fens has greater lability which causes its more intensive decomposition [85]. This is indirectly indicated by higher $\mathrm{CO}_{2}$ emissions from the soils of the fens [86]. Moreover, the peat chemical composition differs between different microtopes. As we can see from the obtained data on the soils of contrasting microtopes, the concentrations of the $\mathrm{DOC}, \mathrm{K}, \mathrm{Na}, \mathrm{Al}, \mathrm{Cu}$, $\mathrm{Zn}$, and $\mathrm{Sr}$ is higher in Histosols of the mounds/polygons compared to the hollows/fens. Thus, it can contribute to bog water enrichment in the DOC, major and trace elements. Indeed, the degree of peat decomposition and elementary content of peat on the mounds is higher than that in the fens/hollows (1.6 times on average). For example, a comparison of peat elementary composition at a depth of $15 \mathrm{~cm}$ at the Pangody site demonstrated higher concentration factors of the major elements $(\mathrm{Ca}, \mathrm{K}$, $\mathrm{Na}, \mathrm{Fe}$ ) and about 40 trace elements in mounds compared to fens/hollows by a factor of 1.5 to 3.5 . Thus, the contribution of plants to the DOC and related elements differentiation in the microrelief should be quite high. However, these connections are more complicated, since the DOC concentrations increase in soil solutions of peat soils occurs to the north, despite the decrease in plant biomass of bogs [7]. Therefore, further studies to identify the role of vegetation in the formation of hydrochemical parameters of the bog water are needed.

\subsection{Prospective Climate Change in Western Siberia}

There are different forecasts for the future state of the cryolithozone. The most likely scenario is moderate temperature growth until the end of the century, following the trend observed in recent decades. However, even these works predict tangible shifts of frozen and natural zones in the 21st century, no less than one zone to the north [87-93]. It has been shown that $74 \%$ of the area of Western Siberia will experience a change in biome type by 2060 [91]. Based on the regional climate model, the main geophysical observatory has shown that by the end of the 21st century, the border of seasonally-developing soils could shift to the Arctic tundra [94]. For the typical tundra of the Yamal Peninsula (Marre-Sale), the complete disappearance of the permafrost layer to depths of $4 \mathrm{~m}$ is possible by 2100 . Similar trends of temperature growth are given in [95] where it is noted that, at the given rate, over a hundred years, the upper $3 \mathrm{~m}$ of soil will be freed from permafrost up to typical tundra. Anisimov et al. [96] indicated that the permafrost at a depth of $320 \mathrm{~cm}$ from the surface in Western Siberia is warming at a rate of $0.15-0.2^{\circ} \mathrm{C}$ every 10 years. Given that the temperature in the area of sporadic and discontinuous permafrost is at least $-1{ }^{\circ} \mathrm{C}$, it can be assumed that it completely melts over 100 years. To the north, in the area of continuous permafrost distribution, the temperature at a given depth is in the range of -2 to $3{ }^{\circ} \mathrm{C}$. Therefore, the permafrost thickness in its upper part should become similar to the more southern sporadic permafrost region. This means that continuously thawed layers will form on the now completely frozen bogs north of $65^{\circ} \mathrm{N}$.

It is important to note that the data underlying the above forecasts were obtained from weather stations located exclusively within the mineral soils; therefore, these forecasts are not directly applicable to wetlands due to the inertia caused by the thermal insulation properties of peat. Forecasting changes in the geocryological conditions of wetlands should be carried out separately from mineral soils. To date, such works are rare. The modeling of the increase in the thickness of the seasonally thawed layer showed that by the end of the century, an increase in the ALT for frozen peatlands will be about $80 \mathrm{~cm}$ [97]. This means that in the zone of discontinuous permafrost, the mounds of frozen bogs will begin to thaw to depths of more than $1 \mathrm{~m}$. This will make them unlikely to freeze in winter so they will become thawed. In addition, $1 \mathrm{~m}$ is more than the average peat thickness of flat mound bogs; therefore, now frozen peat deposits may thaw completely in the future. The geocryological state of the modern polygonal bogs of the southern tundra of the continuous permafrost to the beginning of the 22nd century will be similar to the modern raised-mound bogs of the northern taiga. Lowering speeds of permafrost will vary greatly within bog microtopes, reaching the highest values in fens where taliks are formed, and the annual thawing of polygons will approach depths of $0.5-1 \mathrm{~m}$, depending on the outflow conditions. 
Two main scenarios for the climate warming impact on the Western Siberian peatlands are taking place. According to the first scenario, the areas of fens and hollows will increase and the coverage of palsa by mounds and polygons will decrease $[16,98]$. A similar process is observed, for example, in the north of the Scandinavian Peninsula, where the area of fens and hollows has increased over the past 30 years [99]. The degradation of peat mounds and polygons will be accompanied by the spreading of depressions. As a result, the water coverage of the watershed will increase, thus enhancing the anaerobic conditions. This will increase the fraction of depressions containing less concentrated bog water. On the other hand, the increasing anaerobic conditions may preferentially mobilize redox-sensitive elements ( $\mathrm{Fe}, \mathrm{Mn}, \mathrm{Cr}$, etc.) from the peat to the bog water. Overall, the share of spring runoff from the mounds to the rivers and lakes will decrease, whereas during the summer baseflow, the input from the fens and hollows to the hydrological network will increase. The second scenario assumes no change in micro-relief distribution but a northward retreat of the permafrost boundary and an increase in the ALT $[100,101]$. The ongoing changes and an increase in the active layer of wetlands [102] within the permafrost zone will lead to a change in the dynamics of the DOC and thus, the flows of associated elements $[14,20,103]$. Combining both scenarios, one can expect (1) fast migration of the permafrost boundary via increase of the ALT without changes in the microtope and (2) after several hundred years (following formation of a new peat layer of at least $20 \mathrm{~cm}$ thick), a replacement of mounds by hollows/fens. It is reported that a decade to century period is required for a reorganization of vegetation, water storage, and flow paths in the permafrost landscapes in peaty-silt lowlands [104].

\section{Conclusions}

The considered microtopographic features were shown to have a significant impact on material-energy flows within the elementary geochemical interfaces of frozen raised-mound bogs as well as polygonal and ombrotrophic ridge-hollow raised bogs. The effect of microrelief on temperature regimes and depths of permafrost was most significant. This effect is connected both with the redistribution of heat under the influence of moisture migration and uneven insolation as well as indirectly with the influence of snow cover thickness. These differences can also affect the vegetation, and as a result, the botanical composition of peat and the rate of peat accumulation. All this together is reflected, through the feedback system, in a number of hydrochemical parameters of soil waters, such as $\mathrm{DOC}$, Cond, $\mathrm{SO}_{4}{ }^{2-}, \mathrm{Cl}^{-}, \mathrm{P}, \mathrm{Sr}, \mathrm{Al}, \mathrm{Ti}, \mathrm{Cu}, \mathrm{V}, \mathrm{B}, \mathrm{Cs}, \mathrm{Cd}, \mathrm{Rb}, \mathrm{As}, \mathrm{U}$, and REEs.

Among all studied parameters, the concentrations of $\mathrm{DOC}, \mathrm{SO}_{4}{ }^{2-}, \mathrm{Al}, \mathrm{V}$, and Mn differed most significantly within the convex (mounds, polygons, ridges) and concave (hollows, depressions, fens) landforms. Concentrations of $\mathrm{Cl}^{-}, \mathrm{K}, \mathrm{Li}, \mathrm{B}, \mathrm{Na}, \mathrm{Cr}, \mathrm{Ga}, \mathrm{Mo}, \mathrm{Zn}, \mathrm{Ba}, \mathrm{Pb}, \mathrm{Hf}$, and $\mathrm{W}$ showed indifference to the microtope type. All other parameters showed strong variability between different forms of microrelief within the studied key sites. Therefore, it can be concluded that the local lithological and geomorphological factors little influence on parameters of the bog waters within the microtopes. Additionally, the overall export fluxes of the DOC, major and trace elements from the peatland to the hydrological network are correlated with the water amount that passes through the unfrozen peat layer until the permafrost boundary before being evacuated to the river.

Author Contributions: Conceptualization, O.P., S.L. and T.R.; investigation, A.L., D.K.; methodology, O.P., S.L., T.R.; writing—original draft preparation, S.L., T.R., O.P.; formal analysis, T.R. and A.L.; project administration, S.K. All together we discussed the obtained data and corrected the text.

Funding: The authors acknowledge financial support from the Russian Foundation for Basic Research (projects №16-34-60203-mol_a_dk and 18-05-60264_Arctic) for data acquisition, laboratory researches and manuscript preparation. Data analysis was carried out under support from the Russian Science Foundation (project №18-77-10045).

Acknowledgments: We thank Martyn Rittman for correcting the English language.

Conflicts of Interest: The authors declare no conflicts of interest. The funders had no role in the design of the study; in the collection, analyses, or interpretation of data; in the writing of the manuscript, or in the decision to publish the results. 


\section{Appendix A}

Table A1. Mean values $(\mathrm{M} \pm \mathrm{SD})$ and statistical differences $(p<0.05)$ of DOC, major and trace elements concentration in bog waters of two microtopes. $p$-values are determined by Mann-Whitney U test. Parameters that differ reliably are highlighted in bold.

\begin{tabular}{|c|c|c|c|c|c|c|c|c|c|c|c|c|c|c|c|c|c|c|c|c|c|c|c|}
\hline \multirow{2}{*}{ Parameter } & \multicolumn{4}{|c|}{ KS «Kogalym» } & \multicolumn{4}{|c|}{ KS «Khanymey» } & \multicolumn{4}{|c|}{ KS «Pangody" } & \multicolumn{4}{|c|}{ KS «Urengoy" } & \multicolumn{4}{|c|}{ KS «Tazovsky» } & \multicolumn{3}{|c|}{ All KS } \\
\hline & $\begin{array}{l}\text { mound } \\
(\mathrm{n}=8)\end{array}$ & $\begin{array}{c}\text { hollow } \\
\text { (fen } \\
(\mathrm{n}=8)\end{array}$ & $\mathrm{z}$ & $\mathrm{p}$ & $\begin{array}{l}\text { mound } \\
(\mathrm{n}=34)\end{array}$ & $\begin{array}{c}\text { hollow } \\
\text { (fen } \\
(\mathrm{f}=8)\end{array}$ & z & $\mathrm{p}$ & $\begin{array}{l}\text { mound } \\
(\mathrm{n}=34)\end{array}$ & $\begin{array}{c}\text { hollow } \\
\text { (ffen } \\
(\mathrm{n}=34)\end{array}$ & $z$ & $\mathrm{p}$ & $\begin{array}{c}\text { mound } \\
(\mathrm{n}=3)\end{array}$ & $\begin{array}{c}\text { hollow } \\
\text { (fen } \\
(\mathrm{n}=4)\end{array}$ & $\mathrm{z}$ & $\mathrm{p}$ & $\begin{array}{l}\text { polygon } \\
(\mathrm{n}=20)\end{array}$ & $\begin{array}{c}\text { hollow } \\
\text { (fen } \\
\text { (n= 1) }\end{array}$ & $\mathrm{z}$ & $\mathrm{p}$ & $\begin{array}{l}\text { mound/ } \\
\text { polygon }\end{array}$ & $\begin{array}{c}\text { hollow } \\
\text { /fen }\end{array}$ & $\mathrm{p}$ \\
\hline Cond & $73.8 \pm 21$ & $47.9 \pm 14.5$ & 2.46 & 0.01 & $87.1 \pm 23$ & $61.6 \pm 14$ & 2.95 & $<0.001$ & $72.5 \pm 30.1$ & $51.5 \pm 17$ & 2.17 & 0.03 & $45 \pm 15$ & & 2.12 & & $50.3 \pm 10.1$ & $\begin{array}{l}n=17.7 \\
41.5 \pm 7.7\end{array}$ & 2.24 & 0.03 & $73.4 \pm 27$ & $47.4 \pm 16$ & \\
\hline $\mathrm{pH}$ & & $\begin{array}{r}3.9 \pm 0.4 \\
0.55 \pm 0.30\end{array}$ & $\frac{-0.52}{0.000}$ & 0.60 & $3.5 \pm 0.3$ & & -2.50 & 0.01 & $\begin{array}{l}3.9 \pm 0.2 \\
0.35 \pm 0.3\end{array}$ & & -0.11 & $\begin{array}{l}0.91 \\
083\end{array}$ & & & -2.12 & & & & 0.26 & & $3.78 \pm 0.4$ & $4.06 \pm 0.4$ & $<0.001$ \\
\hline & $\begin{array}{l}0.6 \pm 0.42 \\
0.13 \pm 0.04\end{array}$ & $0.53 \pm 0.30$ & $\frac{0.000}{-0.73}$ & $\frac{1.00}{0.46}$ & $\frac{13 \pm 0.3}{2 \pm \pm 0.5}$ & $\frac{2.24 \pm 0.1}{13 \pm 0.1}$ & 2.84 & 0.07 & $\frac{.03 \pm 0.3}{0.33 \pm 0.3}$ & $\frac{.099 \pm 0.4}{0.12 \pm 0.1}$ & 0.22 & 0.8 .28 & $\frac{0.4 \pm 0.33}{0.81 \pm 0.14}$ & $0.54 \pm 0.41$ & $\frac{-0.35}{2.12}$ & $\frac{0.72}{0.03}$ & 0.31 & $\frac{0.21 \pm 0.1}{0.1 \pm 0.1}$ & 0.16 & $\begin{array}{l}\frac{0.87}{<0.001} \\
<\frac{1}{2}\end{array}$ & 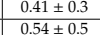 & $\frac{0.35 \pm 0.3}{0.11+0.11}$ & $\begin{array}{l}0.17 \\
<0.001 \\
0<1\end{array}$ \\
\hline & $62.1 \pm 19$ & $36.1 \pm 10.1$ & 2.73 & 0.01 & $82.4 \pm 26$ & & 3.56 & $<0.001$ & $99 \pm 45.9$ & $68.8 \pm 36$ & 1.95 & 0.0 & 74.3 & $50.2 \pm 3.64$ & 1.06 & 0.2 & $79.8 \pm 14.6$ & $50.1 \pm 10.1$ & 4.25 & $<0.001$ & & $3.3 \pm 23$ & $<0.001$ \\
\hline $\begin{array}{l}\text { DIC } \\
\text { Ca }\end{array}$ & $1.35 \pm 0.2$ & $1.43 \pm 0.21$ & -0.63 & 0.53 & $1.68=$ & & 0.75 & 0.45 & $1.8 \pm 0.3$ & $1.78 \pm 0.7$ & 0.79 & 0.4 & $1.36 \pm 0.17$ & & 0.35 & 0. & & $1.74 \pm 0.5$ & -2.24 & .03 & & & 0.89 \\
\hline$\frac{\mathrm{Ca}}{\mathrm{Mg}}$ & $0.73=$ & $\begin{array}{l}0.8 \pm 0.32 \\
0.13+0.66\end{array}$ & $\begin{array}{l}-0.42 \\
0.63\end{array}$ & 0.67 & & & -1.56 & $\begin{array}{ll}0.1 \\
0.0\end{array}$ & & & 2.16 & 0.0. & $\frac{1.13 \pm 0.22}{0.12+0.33}$ & & $\frac{-0.42}{1.95}$ & 0.4 & $\begin{array}{l}3.17 \pm 2.2 \\
042+0.3\end{array}$ & $2.26 \pm 1.4$ & 1.98 & 0.05 & $1.36 \pm 1.4$ & & 33 \\
\hline & 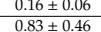 & $\begin{array}{l}\frac{0.13 \pm 0.06}{0.62 \pm 0.39} \\
0.05\end{array}$ & $\frac{0.63}{1.05}$ & 0.53 & $\frac{2 \pm 0.1}{2 \pm 0.1}$ & $\frac{18 \pm 0.1}{48 \pm 0.5}$ & $\frac{-2.56}{-0.41}$ & $\frac{0.0}{0.6}$ & $\frac{.36 \pm 0.3}{0.66 \pm 0.5}$ & $\frac{.32 \pm 0.2}{0.46 \pm 0.3}$ & $\frac{0 .}{0 .}$ & $\frac{0.74}{0.4}$ & $\begin{array}{l}0.12 \pm \pm .6 \\
0.21 \pm 0.6\end{array}$ & $\begin{array}{l}0.19 \pm 0.18 \\
0.16 \pm 0.05\end{array}$ & $\frac{1.95}{-1.41}$ & & $\begin{array}{l}0.42 \pm 0.3 \\
0.28 \pm 0.2\end{array}$ & $\frac{0.48 \pm 0.32}{0.21 \pm 0.1}$ & $\frac{-0.60}{0.28}$ & $\frac{0.55}{0.78}$ & $\frac{0.23 \pm 0.2}{0.43 \pm 0.4}$ & & .02 \\
\hline & & & & & & & & & & & & & & & & & & & & & & & 4.30 \\
\hline $\mathrm{Al}$ & $0.18 \pm 0.08$ & $0.10 \pm 0.05$ & 2.1 & 0.04 & $0.22 \pm 0.1$ & $0.33 \pm 0.1$ & $\frac{1.104}{-2.19}$ & 0.03 & $0.20 \pm 0.19$ & $\frac{.17 \pm 0.1}{0.38 \pm 0.3}$ & $\frac{0.44}{1.50}$ & 0.11 & $0.31 \pm 0$. & $0.18 \pm 0.05$ & 2.10 & & $\begin{array}{l}0.18 \pm 0.1 \\
0.61 \pm 0.4\end{array}$ & $\frac{0.14 \pm 0.02}{0.32 \pm 0.2}$ & $\frac{-0.01}{2.04}$ & 0.04 & 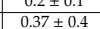 & $\frac{0.17 \pm 0.1}{0.29 \pm 0.2}$ & 1.56 \\
\hline $\mathrm{Fe}$ & $0.86 \pm 0.47$ & $0.59 \pm 0.33$ & 1.26 & 0.21 & $0.44 \pm 0.3$ & $0.68 \pm 0.3$ & -2.19 & 0.0 & $2.08 \pm 1.1$ & $1.61 \pm 0.9$ & 1.41 & 0.14 & $0.90 \pm 0$ & $1.54 \pm 0.6$ & -2.12 & & & $1.53 \pm 0.9$ & -1.53 & 0.13 & & & 0.02 \\
\hline $\mathrm{Si}$ & $0.84 \pm 1$ & $1.17 \pm 0.61$ & 1.99 & 0.048 & $1.31 \pm$ & & & 0.3. & & $2.4 \pm 1.3$ & 1.05 & 0.3 & & & 2.00 & & & & 0.60 & & & & \\
\hline & $0.44 \pm 0.1$ & $0.48 \pm 0.16$ & 0.11 & 0.92 & & & $\frac{-0}{1}$ & & & & & $\begin{array}{ll}0.11 \\
07\end{array}$ & & $0.37 \pm 0.36$ & -1 & & & & & & & & \\
\hline & & & & 0.85 & & & $\frac{1 .}{-1}$ & 0.1 & $66 \pm 1.2$ & $\frac{2.88=}{0.32 .}$ & $\frac{-0.37}{0.53}$ & 0.71 & $\begin{array}{l}0.63 \pm 0.34 \\
0.23+0.1\end{array}$ & & & & & & & 0.02 & $\frac{3 \pm 5.7}{3+0.2}$ & $.07 \pm 3.9$ & $\frac{0.06}{0.75}$ \\
\hline$\frac{\mathrm{Na}}{\mathrm{Ti}}$ & $9 \pm 0.2$ & $\frac{.42 \pm 0.27}{0.96 \pm 0.41}$ & $\frac{0.19}{2.62}$ & 0.85 & $\frac{0.29 \pm 0.1}{2.91 \pm 1.8}$ & & $\frac{-1.19}{0.23}$ & 0.28 & & & $\frac{0.53}{2.95}$ & $\frac{0.60}{<0.0}$ & & $\begin{array}{l}0.25 \pm \\
1.38 \pm\end{array}$ & $\frac{1.06}{1.77}$ & & & & & & & & 001 \\
\hline & 0 & $0.22 \pm$ & 1.97 & 0.05 & & & -0.22 & 0.83 & & & & 0.0 .0 & & & -2.08 & 0 & & & & & & & \\
\hline & & $0.67 \pm 0$ & 0.73 & 0.46 & 1. & & -0.78 & 0.44 & & $1.26 \pm$ & -0.50 & 0.6 & & & -0.35 & & & & 1.49 & 014 & & & 0.33 \\
\hline & & $6.90 \pm 3$ & -0.94 & 0.35 & & & -1 & 0.0 & & & 2.00 & & & & 2.10 & & & & & & & & \\
\hline$\frac{\mathrm{Co}}{\mathrm{Ga}}$ & $\frac{0 .}{0.0}$ & $\frac{0.12 \pm}{0.024 \pm}$ & $\begin{array}{l}1.26 \\
1.57\end{array}$ & $\begin{array}{l}0.21 \\
0.12\end{array}$ & & & $\frac{-2}{0.0}$ & \begin{tabular}{|l|l}
0.0 \\
0.5
\end{tabular} & & $\begin{array}{l}1.05 \pm \\
0.08 \pm\end{array}$ & $\begin{array}{l}1.50 \\
096\end{array}$ & \begin{tabular}{|l|l}
0.1 \\
0.3
\end{tabular} & & & $\begin{array}{l}-0.71 \\
106\end{array}$ & 0 & & & $\frac{0.33}{-1.121}$ & & & & 15 \\
\hline$\frac{\mathrm{Ga}}{\mathrm{As}}$ & & $\frac{0.024 \pm}{0.75 \pm}$ & $\frac{1.57}{1.15}$ & 0.12 & & & $\frac{0 .}{-2}$ & $\frac{0.5}{0.0}$ & & & 0.96 & & & & $\frac{1.06}{0.35}$ & & & & & & & & 35 \\
\hline $\mathrm{Rb}$ & & $0.51 \pm 0.26$ & 2.10 & 0.04 & & & & & & & & & & & & & & & $\begin{array}{l}0.03 \\
-0.09 \\
\end{array}$ & & & & \\
\hline & & & 1.05 & 0.29 & & & -0 & 0.7 & & & 0.04 & & & & 0.00 & & & & 2.04 & & & & \\
\hline $\mathrm{Nb}$ & & & 0.63 & 0.55 & & & & 0.0 & & & & 0.7 & & & & & & & & & & & 1.56 \\
\hline $\begin{array}{l}\text { Mo } \\
\text { Cd }\end{array}$ & & & $\frac{-0.32}{-0.11}$ & 0.7 & & & $\begin{array}{l}-0.38 \\
-178 \\
-178\end{array}$ & 0.0 .8 & & & & & & & & & & & & & & & \\
\hline$\frac{\mathrm{Cd}}{\mathrm{Ni}}$ & 0.7 & $\begin{array}{c}0.14 \pm \\
0.7 \pm 1\end{array}$ & $\frac{-0.11}{0.21}$ & $\frac{0.92}{0.8}$ & 0 & & $\frac{-1.78}{-2.68}$ & $\frac{0.6}{0.6}$ & & & $\begin{array}{l}0.75 \\
1.79\end{array}$ & 0.4 & & & 2.79 & & & & $\frac{1.39}{1.81}$ & & & & 0.56 \\
\hline & & $1.66 \pm$ & & 0.04 & & & $\frac{-2.00}{0.38}$ & & & & & & & & & & & & & & & & \\
\hline $\mathrm{Zr}$ & & & -1.3 & & & & -1 & & & & & & & & & & & & 1.49 & & & & 5 \\
\hline $\mathrm{Sr}$ & & 4.5 & 1.26 & 0.21 & & & -1.40 & 0.1 & & & 2.12 & & & & & & & & 1.76 & & & & 0.85 \\
\hline & & & $\begin{array}{l}-1.05 \\
1.27\end{array}$ & 0.2 & & & & & & & & & & & & & & & & & & & 0.30 \\
\hline & & 0.02 & 1.37 & 0. & & & 0 & & & & & & & & & & & & & & & & $\begin{array}{l}.001 \\
52\end{array}$ \\
\hline$\frac{\mathrm{Ba}}{\mathrm{La}}$ & & & & & & & & & & & & & & & & & & & & & & & \\
\hline & & & $\frac{2.06}{2.10}$ & & & & & & & & & & & & & & & & & & & & \\
\hline$\frac{P_{1}}{1}$ & & & 2.31 & 0.0 & & & -0 & 0.7 & & & & & & & & & & & 2.19 & & & & \\
\hline & & & & & & & & & & & & & & & & & & & & & & & \\
\hline & & & 2.84 & 0.4 & & & & & & & & & & & & & & & & & & & 19 \\
\hline & & & $\frac{2.52}{1.58}$ & 0.0 & & & & & & & & & & & & & & & & & & & 28 \\
\hline$\frac{G a}{T b}$ & & & & 0.1 & & & $\frac{-t}{0}$ & & & & & & & & & & & & & & & & \\
\hline & & & & & & & & & & & & & & & & & & & & & & & \\
\hline $\mathrm{Hc}$ & & & & & & & -1 & 0. & & & & & & & & & & & 88 & & & & 0. \\
\hline & & & 2 & & & & & & & & & & & & & & & & & & & & 24 \\
\hline $\mathrm{Tn}$ & & & & & & & -0 & 0 & & & & & & & & & & & & & & & $\begin{array}{ll}48 \\
94 \\
\end{array}$ \\
\hline & & & $\frac{1.9}{07}$ & $\frac{0.0}{0.04}$ & & & & & & & & & & & & & & & & & & & \\
\hline & & & & & & & & & & & & & & & & & & & & & & & \\
\hline n & & & 0 & & & & & & & & & & & & & & & & & & & & \\
\hline$\overline{T 1}$ & & & 2.0 & 0.04 & & & o. & 0.3 & & & & & & & & & & & 1.48 & 0.1 & & & \\
\hline $\mathrm{PE}$ & & & -0.3. & 0.7 & & & -1.199 & 0.2 & & & & & & & & & & & & & & & 6 \\
\hline & & & & & & & & & & & & & & & & & & & & & & & \\
\hline & & & & & & & & & & & & & & & & & & & & & & & \\
\hline
\end{tabular}


Table A2. Statistical difference $(p<0.05)$ in hydrochemical parameters between bog waters with different hydrological regimes of the KS Tazovsky: 1-polygons occupying elevated dry positions; 2-degraded and flooded polygons and small cracks between polygons; 3-large cracks and fens without watercourse; 4 -lower parts of the fens with watercourse.

\begin{tabular}{|c|c|c|c|c|c|c|c|c|c|c|c|c|c|c|}
\hline \multirow{3}{*}{ Parameter } & \multicolumn{2}{|c|}{$\begin{array}{l}\text { Kruskal-Wallis } \\
\text { (H-test) 1-2-3-4 }\end{array}$} & \multicolumn{12}{|c|}{ Mann-Whitney (U-test) } \\
\hline & \multirow{2}{*}{$\mathbf{H}$} & \multirow{2}{*}{ p-level } & \multicolumn{2}{|c|}{$1-2$} & \multicolumn{2}{|c|}{$1-3$} & \multicolumn{2}{|c|}{$1-4$} & \multicolumn{2}{|c|}{$2-3$} & \multicolumn{2}{|c|}{$2-4$} & \multicolumn{2}{|c|}{$3-4$} \\
\hline & & & $\mathbf{U}$ & $\mathrm{p}$ & $\mathbf{U}$ & $\mathrm{p}$ & $\mathbf{U}$ & $\mathrm{p}$ & $\mathrm{U}$ & $\mathrm{p}$ & $\mathbf{U}$ & $\mathrm{p}$ & $\mathbf{U}$ & $\mathrm{p}$ \\
\hline Cond & 11.9 & 0.007 & 81 & 0.57 & 56 & 0.38 & 6 & 0.008 & 133 & 0.29 & 13 & 0.002 & 18 & 0.012 \\
\hline $\mathrm{pH}$ & 13.2 & 0.004 & 66 & 0.21 & 63 & 0.65 & 2 & 0.002 & 146 & 0.51 & 15 & 0.002 & 13 & 0.005 \\
\hline $\mathrm{Cl}^{-}$ & 1.76 & 0.62 & 22 & 0.3 & 13 & 0.2 & 6 & 0.66 & 27 & 0.56 & 32 & 0.89 & 38 & 0.46 \\
\hline $\mathrm{SO}_{4}^{2-}$ & 18.3 & 0.000 & 20 & 0.016 & 0 & $<0.001$ & 0 & 0.014 & 147 & 0.69 & 12 & 0.033 & 11 & 0.06 \\
\hline DOC & 19.8 & 0.000 & 88 & 0.65 & 46 & 0.15 & 4 & 0.004 & 109 & 0.048 & 0 & $<0.0001$ & 3 & $<0.001$ \\
\hline DIC & 11.4 & 0.01 & 26 & 0.001 & 40 & 0.07 & 25 & 0.53 & 151 & 0.47 & 31 & 0.02 & 36 & 0.19 \\
\hline $\mathrm{Ca}$ & 1.57 & 0.67 & 84 & 0.65 & 71 & 0.97 & 29 & 0.83 & 68 & 0.24 & 51 & 0.24 & 88 & 0.41 \\
\hline $\mathrm{Mg}$ & 7.57 & 0.05 & 72 & 0.32 & 50 & 0.22 & 9 & 0.05 & 93 & 0.96 & 33 & 0.04 & 40 & 0.044 \\
\hline $\mathrm{K}$ & 8.46 & 0.038 & 66 & 0.27 & 24 & 0.015 & 19 & 0.2 & 125 & 0.27 & 66 & 0.85 & 42 & 0.37 \\
\hline $\mathrm{Al}$ & 13.9 & 0.003 & 80 & 0.52 & 43 & 0.22 & 0 & 0.001 & 131 & 0.26 & 12 & 0.001 & 19 & 0.015 \\
\hline $\mathrm{Fe}$ & 10.1 & 0.018 & 78 & 0.59 & 41 & 0.18 & 8 & 0.015 & 113 & 0.14 & 28 & 0.021 & 18 & 0.012 \\
\hline $\mathrm{Si}$ & 0.78 & 0.85 & 90 & 0.18 & 63 & 0.63 & 25 & 0.52 & 63 & 0.16 & 60 & 0.49 & 94 & 0.56 \\
\hline $\mathrm{Li}$ & 6.71 & 0.08 & 40 & 0.34 & 47 & 0.64 & 16 & 0.11 & 102 & 0.07 & 32 & 0.05 & 69 & 0.36 \\
\hline B & 6.96 & 0.07 & 62 & 0.75 & 22 & 0.055 & 1 & 0.055 & 69 & 0.15 & 10 & 0.11 & 38 & 0.15 \\
\hline $\mathrm{Na}$ & 10.8 & 0.013 & 56 & 0.3 & 48 & 0.46 & 3 & 0.24 & 133 & 0.75 & 14 & 0.002 & 33 & 0.09 \\
\hline $\mathrm{Ti}$ & 16.3 & 0.001 & 85 & 0.68 & 56 & 0.68 & 2 & 0.002 & 165 & 0.93 & 0 & $<0.0001$ & 7 & 0.001 \\
\hline V & 16.5 & 0.001 & 72 & 0.32 & 26 & 0.02 & 0 & 0.001 & 139 & 0.38 & 14 & 0.002 & 10 & 0.002 \\
\hline $\mathrm{Cr}$ & 5.21 & 0.15 & 81 & 0.56 & 69 & 0.89 & 13 & 0.055 & 85 & 0.68 & 41 & 0.09 & 46 & 0.054 \\
\hline $\mathrm{Mn}$ & 2.69 & 0.44 & 79 & 0.49 & 68 & 0.84 & 25 & 0.53 & 81 & 0.55 & 46 & 0.15 & 63 & 0.060 \\
\hline Co & 0.57 & 0.9 & 84 & 0.65 & 62 & 0.59 & 27 & 0.67 & 90 & 0.85 & 68 & 0.79 & 108 & 0.983 \\
\hline $\mathrm{Ga}$ & 5.69 & 0.13 & 70 & 0.28 & 57 & 0.41 & 17 & 0.14 & 67 & 0.22 & 26 & 0.055 & 34 & 0.056 \\
\hline As & 8.04 & 0.045 & 77 & 0.69 & 56 & 0.68 & 12 & 0.044 & 129 & 0.65 & 19 & 0.007 & 35 & 0.11 \\
\hline $\mathrm{Rb}$ & 7.01 & 0.07 & 85 & 0.68 & 45 & 0.13 & 17 & 0.138 & 24 & 0.19 & 36 & 0.68 & 36 & 0.054 \\
\hline $\mathrm{Zr}$ & 6.99 & 0.07 & 72 & 0.31 & 58 & 0.45 & 5 & 0.056 & 25 & 0.22 & 20 & 0.11 & 19 & 0.054 \\
\hline $\mathrm{Nb}$ & 11.6 & 0.008 & 80 & 0.53 & 65 & 0.71 & 2 & 0.002 & 162 & 0.87 & 9 & $<0.001$ & 12 & 0.004 \\
\hline Mo & 11.8 & 0.008 & 71 & 0.3 & 54 & 0.32 & 0 & 0.001 & 166 & 0.96 & 14 & 0.002 & 18 & 0.012 \\
\hline $\mathrm{Cd}$ & 9.66 & 0.022 & 91 & 0.89 & 68 & 0.84 & 7 & 0.011 & 158 & 0.77 & 14 & 0.002 & 11 & 0.003 \\
\hline $\mathrm{Ni}$ & 3.63 & 0.3 & 93 & 0.96 & 69 & 0.89 & 18 & 0.17 & 79 & 0.49 & 44 & 0.12 & 49 & 0.053 \\
\hline $\mathrm{Cu}$ & 13.8 & 0.003 & 85 & 0.68 & 34 & 0.07 & 9 & 0.02 & 77 & 0.005 & 15 & 0.002 & 29 & 0.08 \\
\hline $\mathrm{Zn}$ & 3.23 & 0.36 & 58 & 0.21 & 28 & 0.052 & 20 & 0.38 & 90 & 0.85 & 59 & 0.46 & 104 & 0.88 \\
\hline $\mathrm{Sr}$ & 7.65 & 0.06 & 92 & 0.93 & 59 & 0.48 & 16 & 0.11 & 56 & 0.08 & 43 & 0.11 & 81 & 0.26 \\
\hline $\mathrm{Sb}$ & 3.21 & 0.36 & 94 & 1 & 67 & 0.79 & 17 & 0.14 & 84 & 0.65 & 41 & 0.09 & 53 & 0.04 \\
\hline Cs & 10.6 & 0.014 & 83 & 0.61 & 63 & 0.63 & 4 & 0.004 & 126 & 0.2 & 17 & 0.003 & 12 & 0.004 \\
\hline $\mathrm{Ba}$ & 11.1 & 0.011 & 77 & 0.44 & 70 & 0.93 & 8 & 0.015 & 135 & 0.32 & 10 & $<0.0001$ & 24 & 0.035 \\
\hline $\mathrm{La}$ & 10.7 & 0.013 & 81 & 0.56 & 40 & 0.07 & 10 & 0.03 & 113 & 0.09 & 20 & 0.005 & 33 & 0.13 \\
\hline $\mathrm{Ce}$ & 7.77 & 0.05 & 77 & 0.44 & 39 & 0.06 & 11 & 0.05 & 22 & 0.14 & 12 & 0.049 & 48 & 0.18 \\
\hline $\operatorname{Pr}$ & 7.80 & 0.049 & 74 & 0.37 & 42 & 0.09 & 10 & 0.03 & 146 & 0.51 & 29 & 0.019 & 33 & 0.13 \\
\hline $\mathrm{Nd}$ & 7.65 & 0.05 & 70 & 0.28 & 43 & 0.11 & 10 & 0.046 & 68 & 0.24 & 31 & 0.046 & 62 & 0.05 \\
\hline Sm & 9.35 & 0.025 & 59 & 0.11 & 27 & 0.012 & 7 & 0.011 & 155 & 0.7 & 39 & 0.071 & 35 & 0.17 \\
\hline $\mathrm{Eu}$ & 7.54 & 0.05 & 65 & 0.19 & 41 & 0.084 & 10 & 0.046 & 73 & 0.34 & 34 & 0.039 & 62 & 0.05 \\
\hline $\mathrm{Gd}$ & 7.22 & 0.05 & 63 & 0.16 & 42 & 0.095 & 10 & 0.046 & 64 & 0.17 & 37 & 0.05 & 66 & 0.08 \\
\hline $\mathrm{Tb}$ & 6.73 & 0.08 & 65 & 0.19 & 43 & 0.107 & 10 & 0.052 & 69 & 0.26 & 39 & 0.07 & 64 & 0.06 \\
\hline Dy & 6.93 & 0.07 & 64 & 0.17 & 36 & 0.055 & 10 & 0.052 & 68 & 0.24 & 44 & 0.12 & 66 & 0.08 \\
\hline Ho & 6.44 & 0.09 & 67 & 0.22 & 38 & 0.06 & 11 & 0.052 & 67 & 0.22 & 43 & 0.11 & 67 & 0.086 \\
\hline Er & 5.18 & 0.16 & 68 & 0.24 & 43 & 0.11 & 11 & 0.052 & 68 & 0.23 & 51 & 0.24 & 68 & 0.09 \\
\hline $\mathrm{Tm}$ & 4.26 & 0.235 & 70 & 0.28 & 48 & 0.18 & 11 & 0.052 & 66 & 0.2 & 56 & 0.37 & 70 & 0.11 \\
\hline $\mathrm{Yb}$ & 4.37 & 0.224 & 72 & 0.32 & 46 & 0.15 & 11 & 0.052 & 70 & 0.27 & 54 & 0.31 & 70 & 0.11 \\
\hline $\mathrm{Lu}$ & 3.70 & 0.296 & 76 & 0.42 & 48 & 0.18 & 11 & 0.052 & 71 & 0.29 & 57 & 0.39 & 71 & 0.12 \\
\hline $\mathrm{Hf}$ & 4.94 & 0.176 & 76 & 0.42 & 70 & 0.93 & 8 & 0.052 & 79 & 0.49 & 52 & 0.26 & 42 & 0.056 \\
\hline $\mathrm{W}$ & 10.5 & 0.015 & 91 & 0.89 & 57 & 0.73 & 4 & 0.016 & 104 & 0.26 & 5 & 0.002 & 5 & 0.006 \\
\hline $\mathrm{Tl}$ & 8.79 & 0.032 & 76 & 0.52 & 46 & 0.29 & 14 & 0.14 & 117 & 0.28 & 20 & 0.016 & 5 & 0.014 \\
\hline $\mathrm{Pb}$ & 8.95 & 0.030 & 66 & 0.21 & 29 & 0.034 & 25 & 0.53 & 111 & 0.38 & 33 & 0.034 & 37 & 0.146 \\
\hline Th & 20.5 & 0.000 & 41 & 0.02 & 16 & 0.003 & 5 & 0.006 & 123 & 0.17 & 5 & 0.0003 & 18 & 0.012 \\
\hline $\mathrm{U}$ & 15.7 & 0.001 & 84 & 0.65 & 39 & 0.14 & 2 & 0.002 & 120 & 0.15 & 5 & 0.0003 & 19 & 0.015 \\
\hline
\end{tabular}




\section{Appendix B}

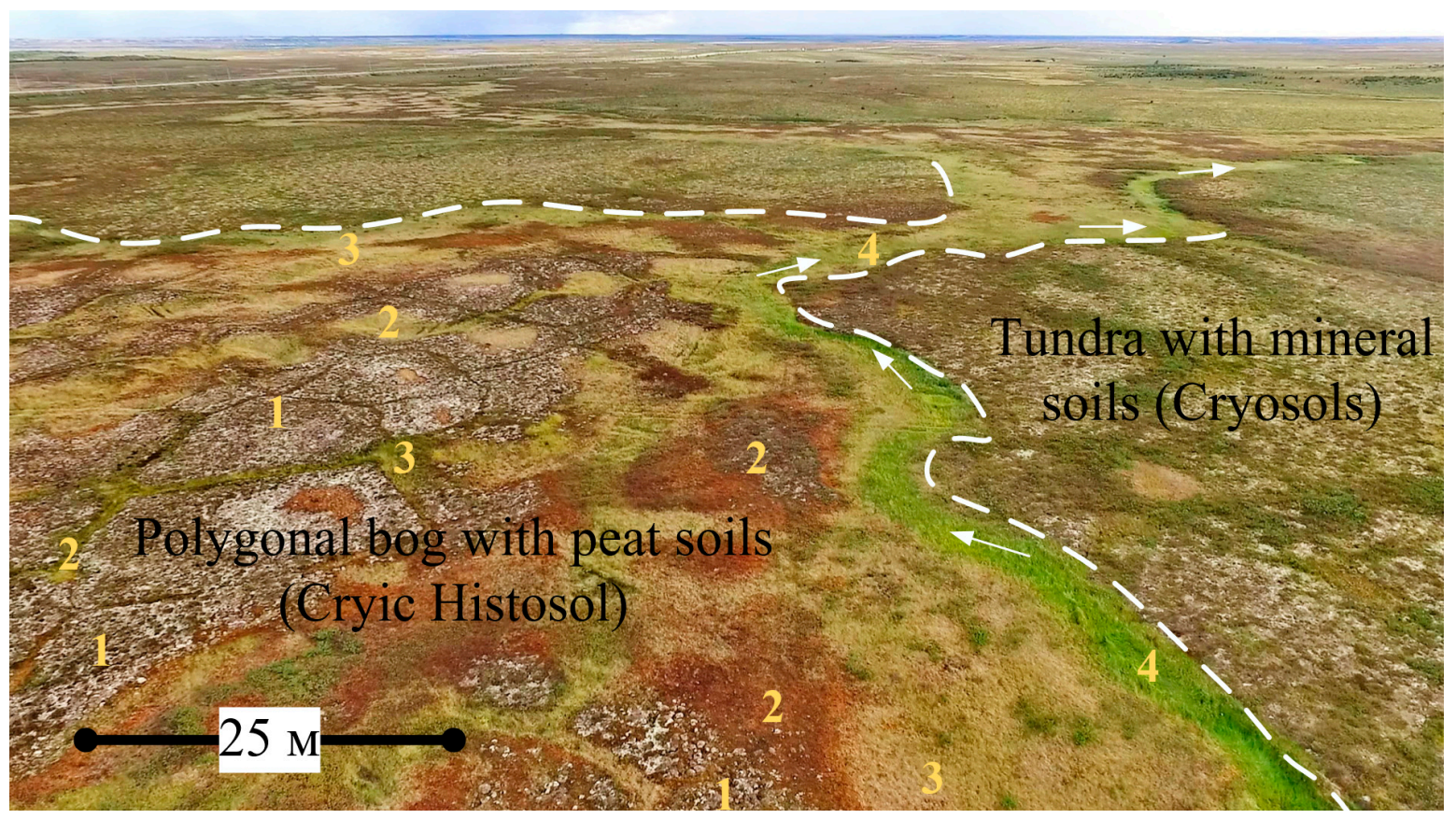

Figure A1. Polygonal bog with microtopes of different hydrological regime at the KS Tazovsky: 1-polygons occupying elevated dry positions; 2-degraded and flooded polygons and small cracks between polygons; 3-large cracks and fens without a watercourse; 4-lower parts of the fens with watercourse. White arrows show the direction of water flow. A white broken line marks the border of a polygonal bog.

\section{References}

1. Liss, O.L.; Abramova, L.I.; Avetov, N.A.; Berezina, N.A.; Inisheva, L.I.; Kurnishkova, T.V.; Sluka, Z.A.; Tolpysheva, T.Y.; Shvedchikova, N.K. Marsh Systems of Western Siberia and Their Conservation Value; Grief and K: Tula, Russia, 2001. (In Russian)

2. Novikov, S.M.; Moskvin, Y.P.; Trofimov, S.A.; Usova, L.I.; Batuev, V.I.; Tumanovskaya, S.M.; Smirnova, V.P.; Markov, M.L.; Korotkevicth, A.E.; Potapova, T.M. Hydrology of Bog Territories of the Permafrost Zone of Western Siberia; BBM publ. House: St. Petersburg, Russia, 2009. (In Russian)

3. Friborg, T.; Soegaard, H.; Christensen, T.R.; Lloyd, C.R.; Panikov, N.S. Siberian wetland: Where a sink is a source. Geophys. Res. Lett. 2003, 30, 2129-2132. [CrossRef]

4. Zemtsov, A.A.; Mezentsev, A.V.; Inisheva, L.I. Marshes of Western Siberia: Their Role in the Biosphere; Publishing House of Tomsk TSNTI: Tomsk, Russia, 1998. (In Russian)

5. Turunen, J.; Tahvanainen, T.; Tolonen, K. Carbon accumulation in West Siberian mires, Russia. Glob. Biogeochem. Cycles 2001, 72, 285-296. [CrossRef]

6. Kirpotin, S.N.; Berezin, A.; Bazanov, V.; Polishchuk, Y.; Vorobiov, S.; Mironycheva-Tokoreva, N.; Kosykh, N.; Volkova, I.; Dupre, B.; Pokrovsky, O.; et al. Western Siberia wetlands as indicator and regulator of climate change on the global scale. Int. J. Environ. Stud. 2009, 66, 409-421. [CrossRef]

7. Raudina, T.V.; Loiko, S.V.; Lim, A.G.; Krickov, I.V.; Shirokova, L.S.; Istigechev, G.I.; Kuzmina, D.M.; Kulizhsky, S.P.; Vorobyev, S.N.; Pokrovsky, O.S. Dissolved organic carbon and major and trace elements in peat porewater of sporadic, discontinuous, and continuous permafrost zones of western Siberia. Biogeosciences 2017, 14, 3561-3584. [CrossRef]

8. Amon, R.M.W.; Meon, B. The biogeochemistry of dissolved organic matter and nutrients in two large Arctic estuaries and potential implications for our understanding of the Arctic Ocean system. Mar. Chem. 2004, 92, 311-330. [CrossRef] 
9. Sukhanova, I.N.; Flint, M.V.; Sergeyeva, V.M.; Kremenetskiy, V.V. Phytoplankton of the southwestern part of the Kara Sea. Oceanology 2011, 51, 1039-1053. (In Russian) [CrossRef]

10. Vasilchuk, Y.K. Modern southern limit of permafrost in Western Siberia Lowland. Earth's Cryosphere 2013, 17, 17-27. (In Russian)

11. Bedritsky, A.I. Global Climate and Soil Cover of Russia: Risk Assessment and Environmental and Economic Impacts of Land Degradation. Adaptive Systems and Environmental Management Technologies (Agriculture and Forestry); GEOS publ.: Moscow, Russia, 2018. (In Russian)

12. Biskaborn, B.K.; Smith, S.L.; Noetzli, J.; Matthes, H.; Vieira, G.; Streletskiy, D.A.; Schoeneich, P.; Romanovsky, V.E.; Lewkowicz, A.G.; Abramov, A.; et al. Permafrost is warming at a global scale. Nat. Commun. Vol. 2019, 10, 1-11. [CrossRef]

13. Paromov, V.V.; Zemtsov, V.A.; Kopysov, S.G. Climate of West Siberia during the slowing phase of warming (1986-2015) and prediction of hydro-climatic resources for 2021-2030. Bull. Tomsk Polytechnic Univ. Geo Assets Eng. 2017, 328, 62-74.

14. Frey, K.E.; Smith, L.C. Amplified carbon release from vast West Siberian peatlands by 2100. Geophys. Res. Lett. 2005, 32, L09401. [CrossRef]

15. Hugelius, G.; Virtanen, T.; Kaverin, D.; Pastukhov, A.; Rivkin, F.; Marchenko, S.; Romanovsky, V.; Kuhry, P. High-resolution mapping of ecosystem carbon storage and potential effects of permafrost thaw in periglacial terrain, European Russian Arctic. J. Geophys. Res. Biogeo. 2011, 116, G03024. [CrossRef]

16. Kaverin, D.A.; Pastukhov, A.V.; Lapteva, E.M.; Biasi, C.; Marushchak, M.; Martikainen, P. Morphology and properties of the soils of permafrost peatlands in the southeast of the Bol'shezemel'skaya tundra. Eurasian Soil Sci. 2016, 49, 498-511. [CrossRef]

17. Vasil'chuk, Y.K.; Vasil'chuk, A.C. Thick polygonal peatlands in continuous permafrost zone of West Siberia. Earth's Cryosphere 2016, 20, 3-13.

18. Kaverin, D.A.; Pastukhov, A.V. Temperature state of soils of peat plateaus in the sporadic permafrost area (European northeast of Russia). Earth's Cryosphere 2018, 21, 42-50.

19. Quinton, W.L.; Hayashi, M. The flow and storage of water in the wetland-dominated central Mackenzie River basin: Recent advances and future directions, in Prediction in Ungauged Basins: Approaches for Canada's Cold Regions. In Prediction in Ungauged Basins: Approaches for Canada's Cold Regions; Spence, C., Pomeroy, J.W., Pietroniro, A., Eds.; Canadian Water Resources Association: Toronto, ON, Canada, 2005; pp. 45-66.

20. Sullivan, P.F.; Arens, S.J.; Chimner, R.A.; Welker, J.M. Temperature and microtopography interact to control carbon cycling in a high arctic fen. Ecosystems 2008, 11, 61-76. [CrossRef]

21. Wright, N.; Hayashi, M.; Quinton, W.L. Spatial and temporal variations in active layer thawing and their implication on runoff generation in peat-covered permafrost terrain. Water Resour. Res. 2009, 45, W05414. [CrossRef]

22. Verry, E.S.; Jansenns, J. Geology, vegetation, and hydrology of the S2 bog at the MEF: 12,000 years in northern Minnesota. In Peatland Biogeochemistry and Watershed Hydrology at the Marcell Experimental Forest; Kolka, R.K., Sebestyen, S.D., Verry, E.S., Brooks, K.N., Eds.; CRC Press: New York, NY, USA, 2011; pp. 93-134.

23. Rhew, R.C.; Teh, Y.A.; Abel, T. Methyl halide and methane fluxes in the northern Alaskan coastal tundra. J. Geophys. Res. 2007, 112, G02009. [CrossRef]

24. Zona, D.; Lipson, D.A.; Zulueta, R.C.; Oberbauer, S.F.; Oechel, W.C. Microtopographic controls on ecosystem functioning in the Arctic Coastal Plain. J. Geophys. Res. Biogeo. 2011, 116, G00I08. [CrossRef]

25. Raudina, T.V.; Loiko, S.V.; Lim, A.; Manasypov, R.M.; Shirokova, L.S.; Istigechev, G.I.; Kuzmina, D.M.; Kylizhsky, S.P.; Vorobyev, S.N.; Pokrovsky, O.S. Permafrost thaw and climate warming may decrease the $\mathrm{CO}_{2}$, carbon, and metal concentration in peat soil waters of the Western Siberia Lowland. Sci. Total Environ. 2018, 634, 1004-1023. [CrossRef]

26. Tang, J.; Yurova, A.Y.; Schurgers, G.; Miller, P.A.; Olin, S.; Smith, B.; Siewert, M.B.; Olefeldt, D.; Pilesjö, P.; Poska, A. Drivers of dissolved organic carbon export in a subarctic catchment: Importance of microbial decomposition, sorption-desorption, peatland and lateral flow. Sci. Total Environ. 2018, 622-623, 260-274. [CrossRef]

27. Wright, N.; Quinton, W.L.; Hayashi, M. Hillslope runoff from an ice-cored peat plateau in a discontinuous permafrost basin, Northwest Territories, Canada. Hydrol. Processes 2008, 22, 2816-2828. [CrossRef] 
28. Trofimova, I.E.; Balybina, A.S. Classification of climates and climatic regionalization of the West-Siberian plain. Geogr. Nat Resour. 2014, 35, 114-122. [CrossRef]

29. Brown, J.; Ferrians, O.J., Jr.; Heginbottom, J.A.; Melnikov, E.S. Circum-Arctic Map of Permafrost and Ground Ice Conditions; NSIDC: Boulder, CO, USA, 2002.

30. Lindsay, R.; Charman, D.J.; Everingham, F.; O'reilly, R.M.; Palmer, M.A.; Rowell, T.A.; Stroud, D.A. The flow Country: The Peatlands of Caithness and Sutherland; Joint Nature Conservation Committee: Peterborough, UK, 1988.

31. Couwenberg, J.; Joosten, H. Self-organization in raised bog patterning: The origin of microtope zonation and mesotope diversity. J. Ecol. 2005, 93, 1238-1248. [CrossRef]

32. Pouliot, R.; Rochefort, L.; Karofeld, E. Initiation of microtopography in revegetated cutover peatlands. Appl. Veg. Sci. 2011, 14, 158-171. [CrossRef]

33. Minayeva, T.Y.; Bragg, O.M.; Sirin, A.A. Towards ecosystem-based restoration of peatland biodiversity. Mires Peat 2017, 19, 1-36.

34. Kosykh, N.P.; Mironycheva-Tokareva, N.P.; Parshina, E.K. Biological productivity of the forest-tundra mires of Western Siberia. Tomsk State Pedagogical Uni. Bull. 2008, 78, 53-57. (In Russian)

35. Kosykh, N.P.; Mironycheva-Tokareva, N.P.; Mikhailova, E.V. Palsa mire. In Soils in the Biosphere, Proceedings of the Russian Scientific Conference with International Participation, Dedicated to the 50th Anniversary of the Institute of Soil Science and Agrochemistry SB RAS, Novosibirsk, Russia, 10-14 September 2018; Publishing House of Tomsk State University: Tomsk, Russia, 2018.

36. Peregon, A.; Maksyutov, S.; Kosykh, N.P.; Mironycheva-Tokareva, N.P. Map-based inventory of wetland biomass and net primary production in western Siberia. J. Geophys. Res.: Biogeosciences 2008, 113, G01007. [CrossRef]

37. Ilina, I.S.; Lapshina, E.I.; Lavrenko, N.N.; Meltzer, L.I.; Romanova, E.A.; Bogoyavlensky, B.A.; Makhno, V.D. Vegetation cover of the West Siberian Plain; Nauka: Novosibirsk, Russia, 1985. (In Russian)

38. Peregon, A.; Uchida, M.; Shibata, Y. Sphagnum peatland development at their southern climatic range in West Siberia: trends and peat accumulation patterns. Environ. Res. Lett. 2007, 2, 045014. [CrossRef]

39. Peregon, A.; Uchida, M.; Yamagata, Y. Lateral extension in Sphagnum mires along the southern margin of the boreal region, Western Siberia. Environ. Res. Lett. 2009, 4, 045028. [CrossRef]

40. World Reference Base for Soil Resources 2014. International soil classification system for naming soils and creating legends for soil maps. World Soil Resources Reports No. 106; FAO: Rome, 2014.

41. Raudina, T.V.; Loyko, S.V.; Kritskov, I.V.; Lim, A.G. Comparison of the composition of soil waters of frozen bogs of Western Siberia, obtained by various methods. Tomsk State Uni.J. Biol. 2016, 35, 26-42. (In Russian) [CrossRef]

42. Prokushkin, A.S.; Pokrovsky, O.S.; Shirokova, L.S.; Korets, M.A.; Viers, J.; Prokushkin, S.G.; Amon, R.; Guggenberger, G.; McDowell, W.H. Sources and export fluxes of dissolved carbon in rivers draining larch-dominated basins of the Central Siberian Plateau. Environ. Res. Lett. 2011, 6, 045212. [CrossRef]

43. Yeghicheyan, D.; Bossy, C.; Bouhnik Le Coz, M.; Douchet, C.; Granier, G.; Heimburger, A.; Lacan, F.; Lanzanova, A.; Rousseau, T.C.C.; Seidel, J.-L.; et al. A compilation of silicon, rare earth element and twenty-one other trace element concentrations in the natural river water reference material SLRS-5 (NRC-CNRC). Geostand. Geoanal. Res. 2013, 37, 449-467. [CrossRef]

44. Pokrovsky, O.S.; Manasypov, R.M.; Loiko, S.; Krickov, I.A.; Kopysov, S.G.; Kolesnichenko, L.G.; Vorobyev, S.N.; Kirpotin, S.N. Trace element transport in western Siberian rivers across a permafrost gradient. Biogeosciences 2016, 13, 1877-1900. [CrossRef]

45. Pokrovsky, O.S.; Manasypov, R.M.; Loiko, S.V.; Shirokova, L.S. Organic and organo-mineral colloids in discontinuous permafrost zone. Geochim. Cosmochim. Ac 2016, 188, 1-20. [CrossRef]

46. Kremenetski, K.V.; Velichko, A.A.; Borisova, O.K.; MacDonald, G.M.; Smith, L.C.; Frey, K.E.; Orlova, L.A. Peatlands of the Western Siberian lowlands: current knowledge on zonation, carbon content and Late Quaternary history. Quaternary Sci. Rev. 2003, 22, 703-723. [CrossRef]

47. Panova, N.K.; Trofimova, S.S.; Antipina, T.G.; Zinoviev, E.V.; Gilev, A.V.; Erokhin, N.G. Holocene dynamics of vegetation and ecological conditions in the Southern Yamal Peninsula according to the results of comprehensive analysis of a relict peat bog deposit. Russian J. Ecol. 2010, 41, 20-27. [CrossRef]

48. Maksimova, L.N.; Ospennikov, E.N. Evolution of mire systems and permafrost of the Bolshezemelskaya tundra in the Holocene. Earth's Cryosphere 2012, 16, 53-61. (In Russian) 
49. Ponomareva, O.E.; Gravis, A.G.; Berdnikov, N.M. Contemporary dynamics of frost mounds and flat peatlands in north taiga of West Siberia (on the example of Nadym site). Earth's Cryosphere 2012, 16, 21-30. (In Russian)

50. Lupachev, A.V.; Gubin, S.V.; Veremeeva, A.A.; Kaverin, D.A.; Pastukhov, A.V.; Yakimov, A.S. Microrelief of the permafrost table: structure and ecological functions. Earth's Cryosphere 2016, 20, 3-14.

51. Inisheva, L.I.; Tsybukova, T.N. Ecological and geochemical assessment of peat in the south-east of the West Siberian Plain. Geogr. Nat. Resour. 1999, 1, 45-51. (In Russian)

52. Inisheva, L.I. Peat soils: Genesis and classification. Eurasian Soil Science 2006, 39, 699-704. [CrossRef]

53. Moskovchenko, D.V. Biogeochemical properties of the high bogs in Western Siberia. Geogr. Nat. Resour. 2006, 1, 63-70. (In Russian)

54. Moskovchenko, D.V.; Babushkin, A.G. Background level of mobile forms of metals in soils of northwest Siberia. UT Res. J. Nat. Resour. Use Ecol. 2015, 1, 163-174. (In Russian)

55. Stepanova, V.A.; Pokrovsky, O.S.; Viers, J.; Mironycheva-Tokareva, N.P.; Kosykh, N.P.; Vishnyakova, E.K. Elemental composition of peat profiles in western Siberia: Effect of the micro-landscape, latitude position and permafrost coverage. Appl. Geochem. 2015, 53, 53-70. [CrossRef]

56. Batuev, V.I. Runoff formation from frost mound bogs (data: West Siberia). TSPU Bull. 2012, 122, $146-152$.

57. Shi, X.; Thornton, P.E.; Ricciuto, D.M.; Hanson, P.J.; Mao, J.; Sebestyen, S.D.; Bisht, G. Representing northern peatland microtopography and hydrology within the Community Land Model. Biogeosciences 2015, 12, 6463-6477. [CrossRef]

58. Ivanov, K.E.; Novikov, S.M. Bogs of Western Siberia, Their Composition and Hydrological Regime; Gidrometeoizdat: Leningrad, Russia, 1976. (In Russian)

59. Olefeldt, D.; Roulet, N.T. Effects of permafrost and hydrology on the composition and transport of dissolved organic carbon in a subarctic peatland complex. J. Geophys. Res. 2012, 117, G01005. [CrossRef]

60. Batuev, V.I. Classification of the primary hydrographic network of frost mound bogs. Tomsk State Pedagog. Uni. Bull. 2010, 93, 70-77. (In Russian)

61. Kaverin, D.A.; Pastukhov, A.V.; Novakovskiy, A.B. Active layer thickness dynamics in the tundra permafrost-affected soils: a calm site case study, the European north of Russia. Earth's Cryosphere 2017, 21, 30-38.

62. Bobrik, A.A.; Goncharova, O.Y.; Matyshak, G.V.; Ryzhova, I.M.; Moskalenko, N.G.; Ponomareva, O.E.; Ogneva, O.A. Correlation of active layer thickness and landscape parameters of peatland in northern West Siberia (Nadym station). Earth's Cryosphere 2015, 19, 29-35.

63. Makhatkov, I.D.; Ermolov, Y.V. The thermal regime of active layer of pit-covered terrain in northern taiga. Internat. J. Appl. Basic Res. 2015, 11, 400-407. (In Russian)

64. Mazhitova, G.G. Soil temperature regimes in the discontinuous permafrost zone in the East European Russian Arctic. Eurasian Soil Sci. 2008, 41, 48-62. [CrossRef]

65. Koronatova, N.G.; Mironycheva-Tokareva, N.P.; Solomin, Y.R. Thermal regime of peat deposits of palsas and hollows of peat plateaus in Western Siberia. Earth's Cryosphere 2018, 22, 16-25.

66. Pokrovsky, O.S.; Manasypov, R.M.; Loiko, S.V.; Shirokova, L.S.; Krickov, I.A.; Pokrovsky, B.G.; Kolesnichenko, L.G.; Kopysov, S.G.; Zemtzov, V.A.; Kulizhsky, S.P.; et al. Permafrost coverage, watershed area and season control of dissolved carbon and major elements in western Siberian rivers. Biogeosciences 2015, 12, 6301-6320. [CrossRef]

67. Kawahigashi, M.; Kaiser, K.; Kalbitz, K.; Rodionov, A.; Guggenberger, G. Dissolved organic matter in small streams along a gradient from discontinuous to continuous permafrost. Glob. Change Biol. 2013, 10, 1576-1586. [CrossRef]

68. Keller, K.; Blum, J.D.; Kling, G.W. Stream geochemistry as an indicator of increasing permafrost thaw depth in an Arctic watershed. Chem. Geol. 2010, 273, 76-81. [CrossRef]

69. Bagard, M.L.; Schmitt, A.D.; Chabaux, F.; Pokrovsky, O.S.; Viers, J.; Stille, P.; Labolle, F.; Prokushkin, A.S. Biogeochemistry of stable $\mathrm{Ca}$ and radiogenic $\mathrm{Sr}$ isotopes in larch-covered permafrost-dominated watersheds of Central Siberia. Geochim. Cosmochim. Ac. 2013, 114, 169-187. [CrossRef]

70. Rudmin, M.; Ruban, A.; Savichev, O.; Mazurov, A.; Dauletova, A.; Savinova, O. Authigenic and detrital minerals in peat environment of Vasyugan swamp western Siberia. Minerals 2018, 8, 500. [CrossRef]

71. Fiałkiewicz-Kozieł, B.; Smieja-Król, B.; Frontasyeva, M.; Słowiński, M.; Marcisz, K.; Lapshina, E.; Gilbert, D.; Buttler, A.; Jassey, V.E.J.; Kaliszan, K.; et al. Anthropogenic- and natural sources of dust in peatland during the Anthropocene. Sci. Rep. 2016, 6, 38731. [CrossRef] 
72. Lim, A.G.; Loyko, S.V.; Raudina, T.V.; Volkova, I.I.; Seredina, V.P. Element composition of peat deposits in flat frost mound bogs of the Pyakupur River (northern taiga of West Siberia). Ukrainian J.Ecol. 2018, 8, $79-87$. [CrossRef]

73. Shevchenko, V.P.; Pokrovsky, O.S.; Vorobyev, S.N.; Krickov, I.V.; Manasypov, R.M.; Politova, N.V.; Kopysov, S.G.; Dara, O.M.; Auda, Y.; Shirokova, L.S.; et al. Impact of snow deposition on major and trace element concentrations and elementary fluxes in surface waters of the Western Siberian Lowland across a 1700 'km latitudinal gradient. Hydrol. Earth Syst. Sci. 2017, 21, 5725-5746. [CrossRef]

74. Opekunova, M.G.; Opekunov, A.Y.; Kukushkin, S.Y.; Ganul, A.G. Background Contents of Heavy Metals in Soils and Bottom Sediments in the North of Western Siberia. Eurasian Soil Sc. 2019, 52, 380-395. [CrossRef]

75. Judd, K.E.; Kling, G.W. Production and export of dissolved C in arctic tundra mesocosms: the roles of vegetation and water flow. Biogeochemistry 2002, 60, 213. [CrossRef]

76. Ma, Q.; Jin, H.; Yu, C.; Bense, V.F. Dissolved organic carbon in permafrost regions: A review. Sci. China Earth Sci. 2019, 62, 349-364. [CrossRef]

77. Kosykh, N.P.; Mironycheva-Tokareva, N.P.; Mikhailova, E.V.; Kolesnichenko, L.G. Vegetation and plant material of the flat palsa peatlands. J. Soils Environ. 2019, 2, e55, (In Russian with English Abstract).

78. Harris, L.I.; Moore, T.R.; Roulet, N.T.; Pinsonneault, A.J. Lichens: A limit to peat growth? J. Ecol. 2018, 106, 2301-2319. [CrossRef]

79. Nikonova, L.G.; Kurganova, I.N.; Lopes de Gerenyu, V.O.; Zhmurin, V.A.; Golovatskaya, E.A. Impact of abiotic factors on the decomposition of litter of peat-forming plants in the incubation experiment. Tomsk State Uni. J. Biol. 2019, 46, 148-170. (In Russian)

80. Golovatskaya, E.A.; Nikonova, L.G. The influence of the bog water level on the transformation of sphagnum mosses in peat soils of oligotrophic bogs. Eurasian Soil Science 2017, 50, 580-588. [CrossRef]

81. Vishnyakova, E.K.; Mironycheva-Tokareva, N.P. Moss decomposition in Western Siberian mires. In Mosses: Ecology, Life Cycle and Significance, 4th ed.; Pokrovsky, O., Volkova, I., Kosykh, N., Shevchenko, V., Eds.; Nova Science Publishers, Inc.: New York, NY, USA, 2018; pp. 217-241.

82. Edwards, K.R.; Kaštovská, E.; Borovec, J.; Šantrůčková, H.; Picek, T. Species effects and seasonal trends on plant efflux quantity and quality in a spruce swamp forest. Plant and Soil 2018, 426, 179-196. [CrossRef]

83. Ritson, J.P.; Bell, M.; Brazier, R.E.; Grand-Clement, E.; Graham, N.J.D.; Freeman, C.; Smith, D.; Templeton, M.R.; Clark, J.M. Managing peatland vegetation for drinking water treatment. Sci. Rep. 2016, 6, 36751. [CrossRef]

84. Zeh, L.; Limpens, J.; Erhagen, B.; Bragazza, L.; Kalbitz, K. Plant functional types and temperature control carbon input via roots in peatland soils. Plant and Soil 2019, 438, 19-38. [CrossRef]

85. Corbett, J.E.; Tfaily, M.M.; Burdige, D.J.; Cooper, W.T.; Glaser, P.H.; Chanton, J.P. Partitioning pathways of $\mathrm{CO}_{2}$ production in peatlands with stable carbon isotopes. Biogeochemistry 2013, 114, 327-340. [CrossRef]

86. Bobrik, A.A.; Ryzhova, I.M.; Goncharova, O.Y.; Matyshak, G.V.; Makarov, M.I.; Walker, D.A. CO 2 Emission and Organic Carbon Pools in Soils of the Northern Taiga Ecosystems of Western Siberia under Different Geocryological Conditions. Eurasian Soil Sci. 2018, 51, 628-636. [CrossRef]

87. Anisimov, O.A.; Shiklomanov, N.I.; Nelson, F.E. Variability of seasonal thaw depth in permafrost regions: A stochastic modeling approach. Ecol. Modelling 2002, 153, 217-227. [CrossRef]

88. Anisimov, O.; Reneva, S. Permafrost and changing climate: the Russian perspective. AMBIO: A J. Hum Environ. 2006, 35, 169-176. [CrossRef]

89. Anisimov, O.A.; Zhiltsova, E.L.; Reneva, S.A. Assessment of critical levels of climate change impacts on natural terrestrial ecosystems in Russia. Meteorol. Hydrol. 2011, 11, 31-41. (In Russian)

90. Anisimov, O.; Kokorev, V.; Zhil'tsova, Y. Temporal and spatial patterns of modern climatic warming: Case study of Northern Eurasia. Clim. Change 2013, 118, 871-883. [CrossRef]

91. Anisimov, O.A.; Sherstiukov, A.B. Evaluating the effect of climatic and environmental factors on permafrost in Russia. Earth's Cryosphere 2016, 20, 78-86.

92. Malkova, G.V.; Gubarkov, A.A.; Drozdov, D.S.; Leybman, M.O.; Khomutov, A.V.; Sherstyukov, A.B. The Second Assessment Report of Roshydromet on Climate Change and Its Consequences on the Territory of the Russian Federation; Roshydromet: Moscow, Russia, 2014.

93. Walvoord, M.A.; Kurylyk, B.L. Hydrologic impacts of thawing permafrost-A review. Vadose Zone J. 2016, 15, 1-20. [CrossRef] 
94. Nadyozhina, E.D.; Shkolnik, I.M.; Pavlova, T.V.; Molkentin, E.K.; Semioshina, A.A. Permafrost response to the climate warming as simulated by the regional climate model of the main geophysical observatory. Earth's Cryosphere 2008, 12, 3-11. (In Russian)

95. Pavlov, A.V.; Malkova, G.V. Small-scale mapping of trends of the contemporary ground temperature changes in the Russian North. Earth's Cryosphere 2009, 13, 32-39. (In Russian)

96. Anisimov, O.A.; Anokhin, A.; Lavrov, S.A.; Malkova, G.V.; Pavlov, A.V.; Romanovskiy, V.E.; Streletskiy, D.A.; Kholodov, A.L.; Shiklomanov, N.I. Continental multiyear permafrost. In Methods of Study the Sequences of Climate Changes for Nature Systems, 1st ed.; Semenov, S.M., Ed.; VNIIGMI: Moscow, Russia, 2012; pp. 268-328. (In Russian)

97. Shkolnik, I.M.; Nadyozhina, E.D.; Pavlova, T.V.; Khlebnikova, E.I.; Semioshina, A.A.; Molkentin, E.K.; Stafeev, E.N. Simulation of the regional features of the seasonal thawing layer in the Siberian permafrost zone. Earth's Cryosphere 2012, 16, 52-59. (In Russian)

98. Moskalenko, N.G. Permafrost and vegetation changes in the Nadym region of West Siberian northern taiga due to the climate change and technogenesis. Earth's Cryosphere 2009, 8, 18-23. (In Russian)

99. Malmer, N.; Johansson, T.; Olsrud, M.; Christensen, T.R. Vegetation, climatic changes and net carbon sequestration in a North-Scandinavian subarctic mire over 30 years. Glob. Change Biol. 2005, 11, 1895-1909. [CrossRef]

100. Sherstyukov, A.B.; Sherstyukov, B.G. Spatial features and new trends in thermal conditions of soil and depth of its seasonal thawing in the permafrost zone. Russ. Meteorol. Hydrol. 2015, 40, 73-78. [CrossRef]

101. Reshetko, M.V.; Moiseeva, Y. Climatic features and statistical evaluation of climate change in permafrost regions in the north of western Siberia. Bull. Tomsk Polytech. Univ. Geo Assets Eng. 2016, 327, 108-118. (In Russian)

102. Guo, D.; Wang, H. Simulated historical (1901-2010) changes in the permafrost extent and active layer thickness in the Northern Hemisphere. J. Geophys. Res.: Atmospheres 2017, 122, 12,285-12,295. [CrossRef]

103. Keuper, F.; Van Bodegom, P.M.; Dorrepaal, E.; Weedon, J.T.; Van Hal, J.; Van Logtestijn, R.S.; Aerts, R. A frozen feast: Thawing permafrost increases plant-available nitrogen in subarctic peatlands. Glob. Change Biol. 2012, 18, 1998-2007. [CrossRef]

104. Jorgenson, M.T.; Harden, J.; Kanevskiy, M.; O’Donnell, J.; Wickland, K.; Ewing, S.; Koch, J. Reorganization of vegetation, hydrology and soil carbon after permafrost degradation across heterogeneous boreal landscapes. Environ. Res. Lett. 2013, 8, 035017. [CrossRef] 